\title{
Oil-weathering behavior in Arctic environments
}

\author{
JAMES R. PAYNE, G, DANIEL MCNABB, JR., and JOHN R. CLAYTON, JR.
}

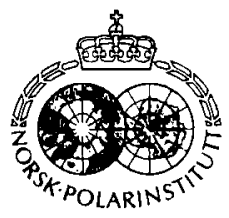

Payne, J. R., McNabb. Jr., G. D. \& Clayton, Jr., J. R. 1991: Oil weathering behavior in Arctic environments. Pp. 631-662 in Sakshaug, E. Hopkins, C. C. E. \& Øritsland, N. A. (eds.): Proceedings of the Pro Mare Symposium on Polar Marine Ecology, Trondheim, 12-16 May 1990. Polar Research 10(2).

Oil-weathering processes in ice-free subarctic and Arctic waters include spreading, evaporation, dissolution. dispersion of whole-oil droplets into the water column, photochemical oxidation, water-in-oil emulsification, microbial degradation, adsorption onto suspended particulate material, ingestion by organisms, sinking, and sedimentation. While many of these processes also are important factors in ice-covered waters, the various forms of sea ice (depending on the active state of ice growth, extent of coverage and/or decay) impart drastic, if not controlling, changes to the rates and relative importance of different oil-weathering mechanisms. Flow-through seawater wave-tank experiments in a cold room at $-35^{\circ} \mathrm{C}$ and studies in the Chukchi Sea in late winter provide data on oil fate and effects for a variety of potential oil spill scenarios in the Arctic. Time-series chemical weathering data are presented for Prudhoe Bay crude oil released under and encapsulated in growing first-year columnar ice through spring breakup.

James R. Payne*, G. Daniel McNabb, Jr., and John R. Clayton, Jr., Science Applications International Corporation, 10240 Sorrento Valley Road, Suite 204, San Diego, California 92121, USA.

\section{Introduction}

This paper considers the results of NOAA-sponsored laboratory and field studies on the timedependent physical and chemical changes that occur to oil released in open-ocean and ice-covered waters. Data from these studies were used for the development and verification of computer models to predict the behavior of crude oils and refined petroleum products spilled into a variety of subarctic and Arctic marine environments (Payne et al. 1983, 1984, 1987a,b, 1989, and 1991a).

The following section briefly considers oil characterization and discusses the physical and chemical properties that are most affected by weathering processes. Oil-weathering behavior of Prudhoe Bay crude oil in open-ocean (ice-free) conditions is reviewed briefly, and changes in oil's physical properties, oil-phase chemistry, and water column concentrations of dissolved and dispersed hydrocarbons are summarized. The results of oil-weathering studies in ice-covered waters are presented in detail and the effects of ice dynamics on controlling oil-weathering behavior are contrasted with open-ocean conditions. These data are then used to call attention to a dissolved aromatic hydrocarbon transport process that is unique to Arctic environments.

\footnotetext{
* Present Address: Sound Environmental Services, Inc., 2236 Rutherford Rd.. Suite 103, Carlsbad. California 92008, USA.
}

\section{Oil characterization}

Oil companies use several bulk physical properties to characterize crude oils, including the API Gravity (density), viscosity, pour point, asphaltene content, and the presence of trace constituents (Table 1). The specific gravity of most oils and refined products is less than one. Thus, when such oil is released at sea, it will not sink directly in the absence of incorporated sedimentary material, additional weathering, and/or ingestion of small droplets by zooplankton and deposition as fecal pellets (NAS 1985). The temperature-dependent properties of viscosity and pour point also are important because they affect the spreading of oil on the water surface and the dispersion of whole-oil droplets into the water column (Jordan \& Payne 1980; Payne et al. 1987c). The viscosity of most fresh crude oils ranges from $18-100$ centipoise measured at $38^{\circ} \mathrm{C}$. Viscosity is higher at colder ocean-water temperatures (Gold 1969), and it will undergo rapid changes during oil weathering. The pour point of the oil is particularly important at the time of a spill. If the ambient temperature is below the pour point of the oil or refined product, it will not flow readily and/or spread on the water surface. This phenomenon occurred during the 1989 PRESIDENTE RIVERA spill of No. 6 fuel oil (with a pour point of $95^{\circ} \mathrm{F}$ ) in the Delaware River and the 1970 tanker ARROW oil spill off Chedabucto Bay, Nova Scotia (Barber 1970). In these instan- 
Table 1. Gross characterizations of four selected whole crude oils (from Payne et al. 1984)

\begin{tabular}{|c|c|c|c|c|c|c|c|c|c|c|}
\hline Crude Oil & $\begin{array}{l}\text { API } \\
\text { gravity }\end{array}$ & $\begin{array}{l}\text { Specific } \\
\text { gravity } \\
\mathrm{g} \mathrm{ml}^{-1}\end{array}$ & $\begin{array}{l}\text { Viscosity } \\
\text { Kinematic } \\
\text { cST }\end{array}$ & $\begin{array}{l}\left(100^{\circ} \mathrm{F}\right) \\
\text { Saybolt } \\
\text { SUS }\end{array}$ & $\begin{array}{l}\text { Pour } p t^{b} \\
{ }^{\circ} \mathrm{F}\end{array}$ & $\begin{array}{l}\text { Percent } \\
\text { Asphalt }\end{array}$ & $\begin{array}{l}\mathrm{Ni} \\
\mathrm{ppm}\end{array}$ & $\begin{array}{l}\mathrm{V} \\
\mathrm{ppm}\end{array}$ & $\begin{array}{l}\mathrm{S} \\
\%\end{array}$ & $\begin{array}{l}\mathrm{N}^{\mathrm{d}} \\
\%\end{array}$ \\
\hline Murban, Abu Dhabi & 40.5 & 0.829 & 2.8 & 35.9 & -20 & 7 & 3.0 & 9.9 & 0.96 & 0.10 \\
\hline Cook Inlet, Alaska & 35.4 & 0.848 & 17 & 85 & -15 & 12 & 1.3 & 0.47 & 0.09 & 0.11 \\
\hline Prudhoe Bay, Alaska & 27.0 & 0.893 & 19 & 84 & -10 & 23 & 13.5 & 28.3 & 0.98 & 0.25 \\
\hline Wilmington, California & 19.4 & 0.938 & 100 & 470 & $<5^{a}$ & 24 & 100 & 80.6 & 1.8 & 0.83 \\
\hline
\end{tabular}

Sources:

a Coleman et al, 1978

b Evaluation of Worlds Important Crudes, 1973

calculated from Conradson Carbon Value. Coleman et al. 1978

${ }^{d} \mathrm{Ni}, \mathrm{V}, \mathrm{S}$, and $\mathrm{N}$ : this study

ces, the oil moved like semisubmerged strands of thick rope or "icebergs"; the majority of the bulk oil resided just below the water surface. Asphaltene content is important because it affects the potential for spilled oil to form a stable water-inoil emulsion or mousse (Berridge et al. 1968a, b; Bridie et al, 1980a, b; Payne \& Phillips 1985a and references therein). Traces of $\mathrm{Ni}$ and $\mathrm{V}$ contained in oil as metalloporphyrins also can be important in stabilizing emulsions and affecting weathering behavior (Payne \& Phillips 1985a; Canevari 1985; NAS 1985).

Oil companies also characterize crude oils by distillation curves which represent the percentage of product distilled as a function of temperature or boiling point (Fig. 1); however, there is a considerable volume and weight percentage (30$50 \%$ ) of many crudes that is not readily distillable. The higher molecular weight waxes, asphaltenes, and other materials in the so-called nondistillable residuum (b.p. $>800^{\circ} \mathrm{F}$ ) are not subject to any significant weathering alterations (with the possible exception of longer term microbial degradation of the waxes; Bartha \& Atlas 1987; Haines \& Alexander 1974), and they also play an important role in the formation of stable water-in-oil emulsions. Refined products (gasoline, diesel, fuel oils, etc.) are produced by collecting distillate cuts in different lower boiling-point ranges (Clark \& Brown 1977).

For environmental considerations, crude oils and refined products are characterized by techniques such as capillary gas chromatography to assess specific component concentrations for evaluating volatility, water solubility, and toxicity. The chromatograms of the aliphatic and aromatic fractions of Prudhoe Bay crude oil (Fig. 2) illus-

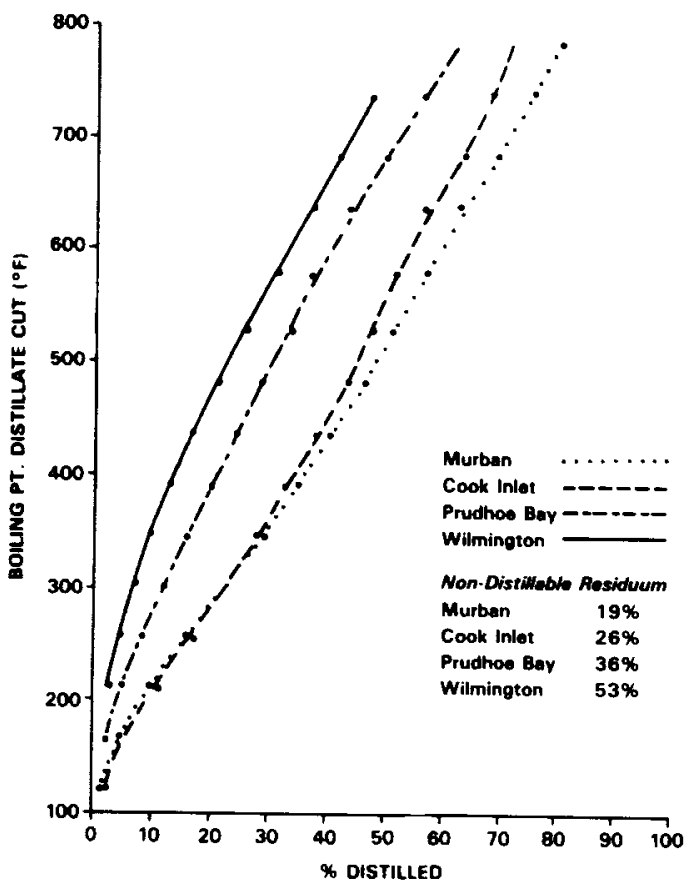

Fig. 1. Boiling point distillation curves for four selected crude oils (from Payne et al. 1984).

trate the complexity of the mixtures that constitute fresh crude oils. The aliphatic fraction (Fig. $2 \mathrm{~A}$ ) is characterized by an evenly repeating series of straight-chain $n$-alkanes from $n-C_{8}$ (Kovats Retention Index 800; Kovats 1958) through $n-C_{30}$ along with branched and cyclic components at lesser concentrations. The n-alkanes in Prudhoe Bay crude oil actually predominate out to $n-C_{50}$ or greater, although only the relatively lighter 
Fig. 2. Flame ionization detector (FID) capillary gas chromatograms obtained on $\mathrm{SiO}_{2}$ fractionated Prudhoe Bay crude oil. A. Aliphatic fraction (F1). B. Aromatic fraction (F2) (from Payne et al. 1984).
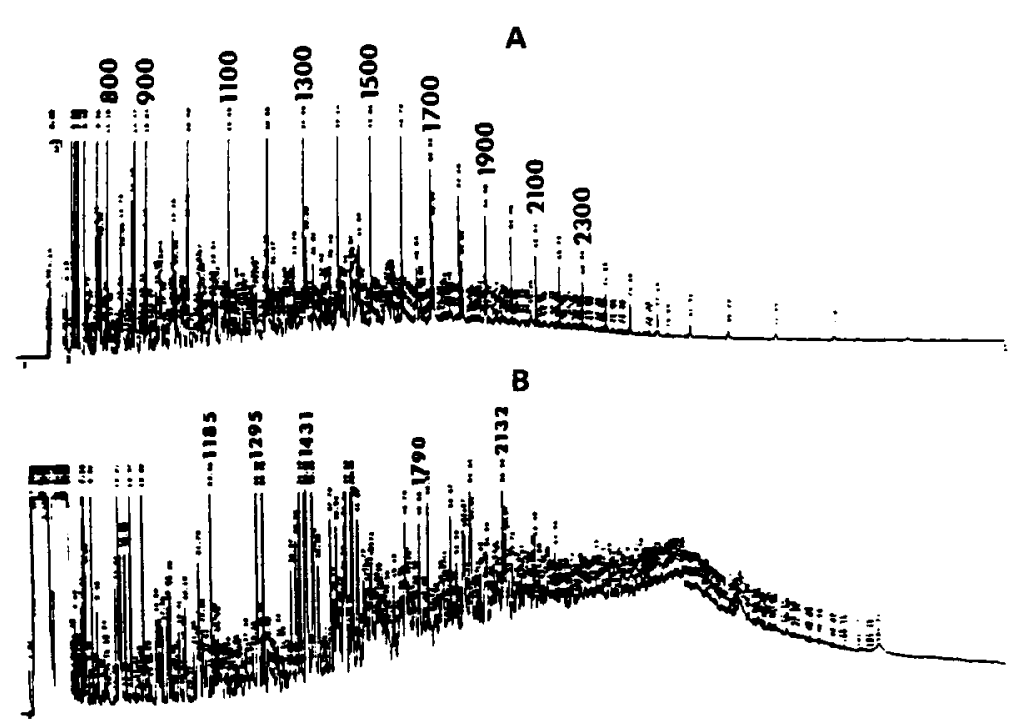

ones are represented in the chromatogram because of the temperature conditions under which it was generated. The isoprenoid components, pristane (Kovats Index 1710) and phytane (Kovats Index 1815), also are important because their relative resistance to bacterial degradation (compared to n-alkanes) can help differentiate between biological and abiotic degradation processes over time (Pirnik 1977; Bartha \& Atlas 1987). The chromatogram of the aromatic fraction (Fig. 2B) differs from its aliphatic counterpart, and it is characterized by peaks representing one-, two-, three-, and fourring polynuclear aromatic hydrocarbons and their alkyl-substituted homologues. In most crudes these alkyl-substituted aromatics predominate over the unsubstituted parent aromatic components (Payne et al. 1984). Identities of many of these components are presented in Table 2, which lists the Kovats Retention Indices and concentrations of a variety of parent aromatic components and their alkyl-substituted homologues in fresh and partially weathered Prudhoe Bay crude oil. As shown by the data in the table, the most prominent aromatic component in fresh Prudhoe Bay crude is 2-methylnaphthalene; however, in the weathered crude, only the dimethylnaphthalenes and higher molecular weight aromatics persist.

When oil is released into an aqueous environ- ment, the water-soluble components reside principally in the aromatic fraction (Clark \& MacLeod 1977 and references therein). Thus, chromatograms from extracts of dissolved components from water column samples obtained immediately after an oil spill will be very similar to the one shown in Fig. 2B, particularly for the lower molecular weight one- and two-ring components. The higher molecular weight components, with Kovat indices $>1413$ (dimethylnaphthalene), would not be as prevalent in the water column samples because of their more limited water solubilities (see below). In this instance the chromatogram was obtained by chemical separation of the aliphatic and aromatic components by silica gel $\left(\mathrm{SiO}_{2}\right)$ column chromatography using a four-solvent fractionation scheme (Payne \& Floyd 1990). While the relative concentrations (peak heights) of the aliphatic and aromatic components appear similar in these chromatograms, it should be noted that the aliphatics are present in the starting crude oil at concentrations almost 10 times higher than the aromatics. Thus, a chromatogram of fresh unfractionated Prudhoe Bay crude oil or dispersed oil droplets from water column samples would more closely resemble the one shown in Fig. 2A. The absolute ratio of aliphatics to aromatics varies significantly among different crude oils, but the aliphatics generally predominate (NAS 1985). 
Table 2. Typical aromatic hydrocarbon concentrations in fresh and weathered Prudhoe Bay crude oil.

\begin{tabular}{|c|c|c|c|}
\hline \multicolumn{2}{|c|}{ Aromatic component (Kovats Retention Index) } & \multicolumn{2}{|c|}{$\begin{array}{c}\text { Concentration }\left(\mu \mathrm{g} \mathrm{g}^{-1} \text { oil) }\right. \\
\text { Weathered } \\
\text { (on water under a } 7-\mathrm{knot} \text { wind at } 19^{\circ} \mathrm{C} \text { ) }\end{array}$} \\
\hline & Fresh & 9 days & 20 days \\
\hline Ethylbenezene (856) & 30 & 0 & 0 \\
\hline 1,4-\&1,3-dimethylbenzene (867) & 120 & 0 & 0 \\
\hline 1,2-dimethylbenzene (893) & 110 & 0 & 0 \\
\hline Propylbenzene (951) & 16 & 0 & 0 \\
\hline 1-ethyl-2-methylbenzene (959) & 140 & 0 & 0 \\
\hline 1-methylethylbenzene (977) & 80 & 0 & 0 \\
\hline 1,2,4-trimethylbenzene ( 991 ) & 320 & 0 & 0 \\
\hline 1,2,X-trimethylbenzene (1019) & 280 & 0 & 0 \\
\hline 1.2.3.5-tetramethylbenzene (1148) & 130 & 0 & 0 \\
\hline 1,2.3.4-tetramethylbenzene (1156) & 150 & 0 & 0 \\
\hline Naphthalene (1179) & 520 & 0 & 0 \\
\hline 2-methylnaphthalene (1288) & 1,500 & 17 & 0 \\
\hline 1-methylnaphthalene (1304) & 990 & 20 & 0 \\
\hline 1.1-biphenyl (1375) & 160 & 17 & 0 \\
\hline 2-ethylnaphthalene (1387) & 220 & 40 & 0 \\
\hline 1.5-dimethylnaphthalene (1398) & 860 & 185 & 60 \\
\hline 2.3-dimethylnaphthalene (1413) & 230 & 70 & 50 \\
\hline Fluorene (1589) & 83 & - & - \\
\hline Dibenzothiophene (1744) & 330 & 210 & 400 \\
\hline Phenanthrene (1771) & 270 & 240 & 350 \\
\hline 4-methyldibenzothiophene (1845) & 250 & 240 & 360 \\
\hline 2-methylphenanthrene (1887) & 160 & 160 & 200 \\
\hline X-methylphenanthrene (1911) & 210 & 150 & 270 \\
\hline 2.3-dimethylphenanthrene (2027) & 270 & 250 & 380 \\
\hline Fluoranthene (2070) & 50 & - & - \\
\hline Pyrene $(2120)$ & 63 & - & - \\
\hline Chrysene or benzo(a)anthracene (2468) & 30 & - & - \\
\hline
\end{tabular}

\section{Oil weathering in open-ocean subarctic and Arctic waters}

To evaluate temporal changes in the physical and chemical properties of crude oil in ice-free subarctic marine environments, a series of summer and winter outdoor flow-through seawater wavetank experiments were conducted at the NOAA field laboratory at Kasitsna Bay (Homer), Alaska.

The results of the summer outdoor oil weathering experiments have been presented previously (Payne et al. 1983, 1984; Payne \& McNabb 1984), and most recently they have been compared with oil weathering behavior observed in Prince William Sound after the release of 11 million gallons of North Slope crude oil from the EXXON VALDEZ (Payne et al. 1991a).

\section{Oil phase physical and chemical properties} changes during open-ocean oil weathering

During the summer wave tank experiments, the water content of the oil remained at less than $5 \%$ for the first 24 hours, increasing to $50-60 \%$ over the next six to 10 days. During this weathering process, the density increased from 0.88 to $0.98 \mathrm{~g} \mathrm{ml}^{-1}$ due to the evaporation of lighter hydrocarbons and water incorporation; however, this density increase was insufficient for the emulsified oil to sink. If water contains adequate suspended particulate material (SPM), the interaction of dispersed oil droplets with SPM can enhance sedimentation; but this is not a significant factor unless SPM concentrations exceed $100 \mathrm{mg} \mathrm{l}^{-1}$ in the water column (Boehm 1987; Payne et al. $1987 \mathrm{~b}, \mathrm{c}$ ).

The oil/water interfacial surface tension also changed over time, decreasing from 27 dynes $\mathrm{cm}^{-1}$ to $10-14$ dynes $\mathrm{cm}^{-1}$ with the incorporation of water and the formation of photo-oxidation (Payne \& Phillips 1985b) and possibly microbial degradation products. However, the oil/air interfacial surface tension essentially remained unchanged.

The viscosity $\left(38^{\circ} \mathrm{C}\right)$ increased from 16 centipoise to 2,800 centipoise over the first 12 days of 
Table 3. Viscosity measurements at ambient temperatures in wave tanks.

A. Observed ${ }^{2}$ vs. model-predicted data from the summer wavetank spills.

\begin{tabular}{rrrrr}
\hline & \multicolumn{2}{c}{$\begin{array}{c}\text { Viscosity } \\
\text { (centipoise) }\end{array}$} & \multicolumn{2}{c}{$\begin{array}{c}\text { Water incorporation } \\
\text { (percent by weight) }\end{array}$} \\
Time (hours) & Observed & Predicted & Observed & Predicted \\
\hline 1 & 68 & 160 & $<0.10$ & 0.96 \\
2 & 130 & 190 & $<0.10$ & 1.9 \\
4 & 220 & 240 & 0.15 & 3.7 \\
8 & 340 & 320 & $<0.10$ & 7.4 \\
12 & 620 & 410 & 0.22 & 10.0 \\
24 & 690 & 630 & 18.0 & 19.0 \\
48 & 1,080 & 1,300 & 34.0 & 33.0 \\
72 & 2,350 & 2,000 & 49.0 & 44.0 \\
144 & 5,400 & 6,500 & 50.0 & 58.01 \\
216 & 6,200 & 8,450 & 51.0 & 60.17 \\
\hline
\end{tabular}

${ }^{3}$ Based on the average values from three wave tanks.

' Observed viscosity data were obtained at ambient temperature (averaging $58^{\circ} \mathrm{F}$; predicted values were calculated using a temperature of $55^{\circ} \mathrm{F}$ ).

B. Observed ${ }^{\text {a }}$ vs. model-predicted data from the fall/winter wave-tank spills.

\begin{tabular}{ccc}
\hline Time (hours) & \multicolumn{2}{c}{ Viscosity (centipoise) $^{\mathrm{b}}$} \\
Predicted $^{(25)}$ & Observed & 730 \\
\hline 1 & 270 & 830 \\
2 & 280 & 980 \\
4 & 580 & 1,200 \\
8 & 2,200 & 1,300 \\
12 & 2,900 & 1,800 \\
24 & 5,600 & 3,400 \\
75 & 8,700 & 6,400 \\
144 & 9,800 & 16,000 \\
288 & 11,500 & \\
\hline
\end{tabular}

a Based on a single wave tank experiment.

o Observed viscosity data were obtained at ambient temperature (averaging $30-32^{\circ} \mathrm{F}$; predicted values were calculated using a temperature of $30^{\circ} \mathrm{F}$ ).

the experiment due both to evaporation weathering and water-in-oil emulsion formation. These values were obtained at a laboratory-controlled temperature of $38^{\circ} \mathrm{C}$ to provide maximum reproducibility, and as noted earlier, viscosity is temperature dependent. When measured at the ambient temperatures in the wave tanks, viscosity increases are more apparent (Table 3). During the summer experiments (i.e., ambient temperature $12-14^{\circ} \mathrm{C}$ ), viscosity increased from around 68 to 2,300 centipoise after only three days. For the fall/winter ice-free experiments at $2-4^{\circ} \mathrm{C}$, the viscosity increases were more significant, with initial values increasing from 270 to 5,600 centipoise after only 24 hours.
Viscosity probably is the most important physical property considered because of its effect on various oil spill countermeasures and cleanup options. Oils with viscosities greater than 2,000 centipoise are difficult to disperse chemically (NAS 1989), and it is evident that response actions using dispersants must be initiated almost immediately after a spill in order to be effective. In addition, viscosity affects the ability to pump oil after it is collected.

The water content of oil also limits response options by increasing the volume of material that must be handled and stored. For heavier crude oils, water content above $20-30 \%$ makes in situ combustion essentially impossible (Twardus 1980).

Spilled oil undergoes rapid evaporation/ dissolution weathering. Under the spring/ summer conditions simulated in the wave-tank systems, all compounds with vapor pressures greater than $n-C_{11}$ (b.p. $<400^{\circ} \mathrm{F}$ ) were lost within the first nine days (Payne et al. 1984, 1991a). Between the period from two weeks and seven months, there was an additional loss of compounds between $n-C_{11}$ and $n-C_{13}$ (b.p. $450^{\circ} \mathrm{F}$ ); however, under subarctic winter conditions, there was little evidence of microbial degradation. Ratios of $n-C_{17} /$ pristane and $n-C_{18} /$ phytane were essentially unchanged over that period. Between late spring and the following summer/fall, however, there was a significant change in the straightchain/branched-chain hydrocarbon ratios due to selective bacterial degradation of the n-alkanes in preference to the isoprenoid components. When weathered material was sloughed off the tarball surfaces, undegraded material appeared, which slowly degraded until the tarballs were fragmented into flakes and droplets small enough to be assimilated into the water column by gentle wave turbulence. Under such conditions, bacterial processes in the water column also become an important, if not critical, factor in the ultimate removal of the oil from the ecosystem.

\section{Water column chemistry}

To assess water-column oil concentrations following the spill, 20-liter subsurface seawater samples were filtered through a $0.4-\mu \mathrm{m}$ poresized, $293-\mathrm{mm}$ diameter glass-fibre filter for analysis of the dissolved components and dispersed- and/or particulate-bound oil droplets. Chromatograms of dissolved components 


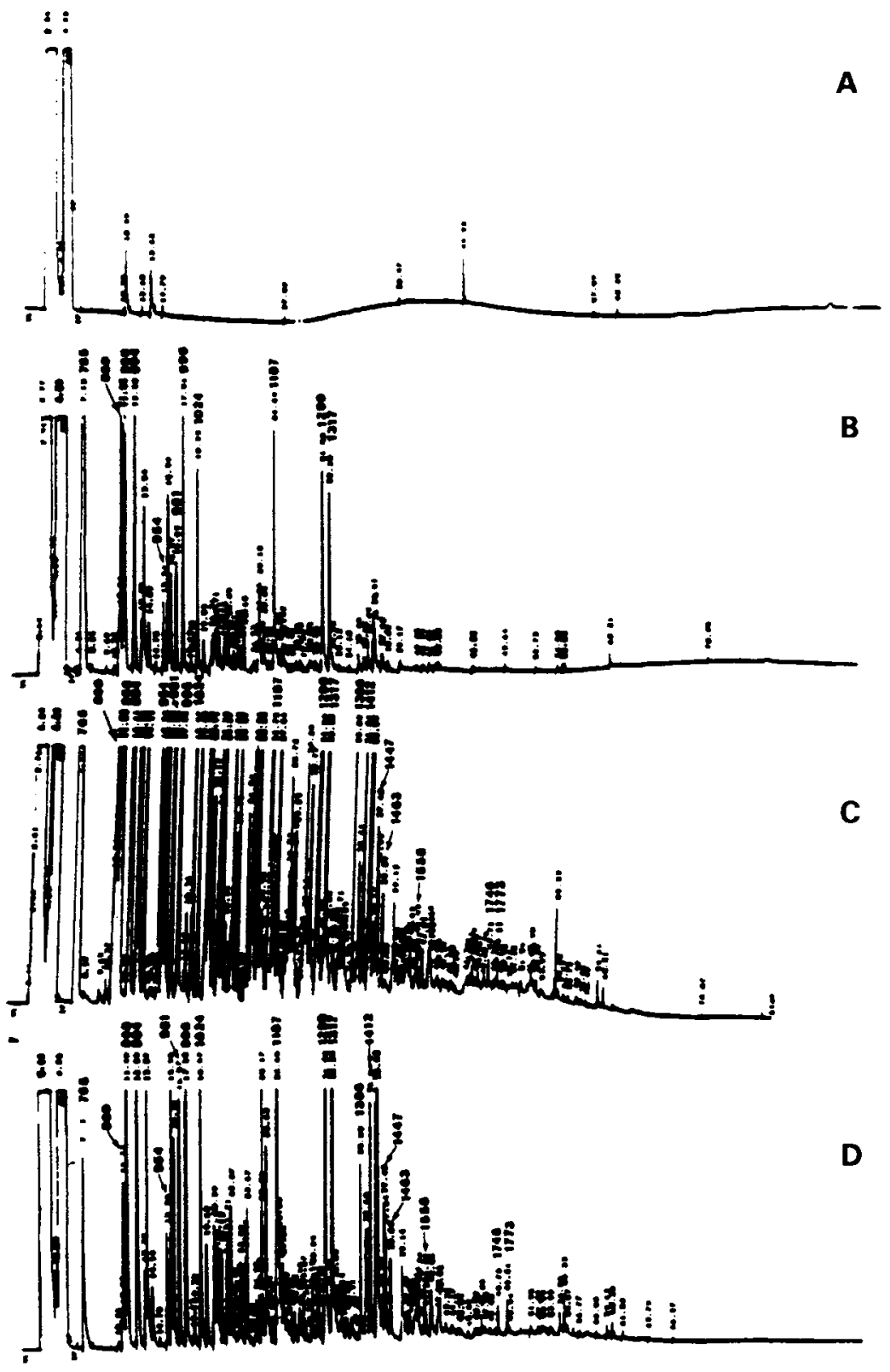

Fig. 3. FID gas chromatograms of filtered seawater extracts (dissolved components) from summer wave-tank experiments at (A) prespill blank, (B) five minutes, (C) eight hours and (D) 48 hours after a spill of 16 liters of Prudhoe Bay crude oil. measured in time-series filtered seawater samples from the flow-through wave-tank systems are shown in Figs. 3 and 4. Dissolution of lower molecular weight aromatic components occurs after as little as five minutes (Payne et al. 1983). The chromatograms from filtered seawater samples collected during the early stages of the spill show very similar profiles for the lower molecular weight aromatics (Kovats Index values
$<1400$ ) when compared to the chromatogram of the aromatic fraction obtained from silica gel fractionation of whole fresh Prudhoe Bay crude oil (Fig. 2B). Dissolved-phase chromatograms are characterized only by the individual aromatic components, not by the evenly repeating series of n-alkanes that predominate in the whole (unfractionated) oil samples. The major dissolved components include benzene, toluene, xylenes, 
Fig. 4. FID gas chromatograms of filtered seawater extracts (dissolved components) from summer wave-tank experiments at (A) 12 days, (B) four months, and (C) 12 months after a spill of 16 liters of Prudhoe Bay crude oil.
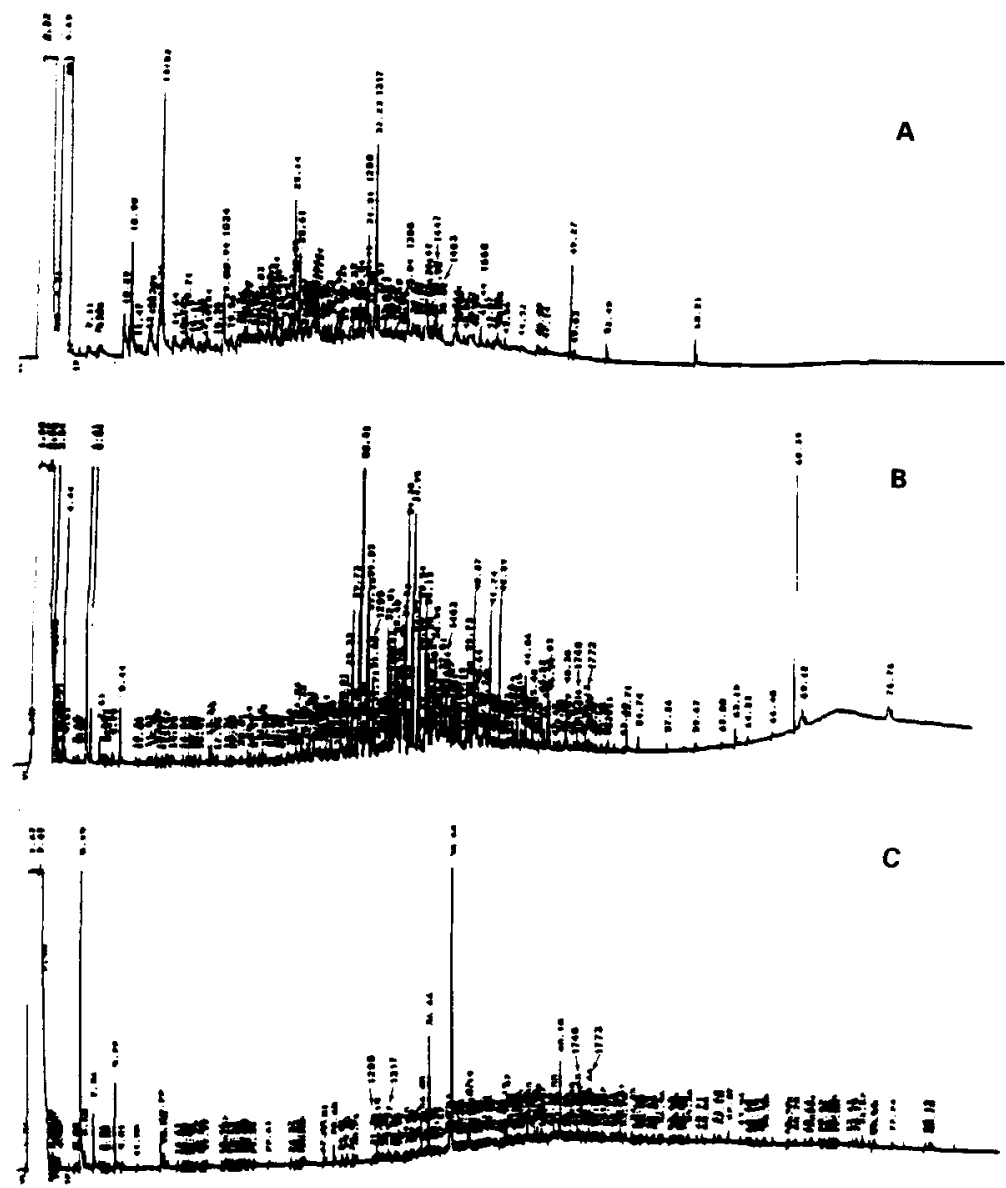

ethyl-benzene, $\mathrm{C}_{3}$-substituted benzenes, naphthalene, methyl-naphthalene, $\mathrm{C}_{2^{-}}$and $\mathrm{C}_{3}$-substituted naphthalene, phenanthrene, and $\mathrm{C}_{1^{-}}$and $\mathrm{C}_{2}$-substituted phenanthrene. Kovats Retention Indices for many of these components are shown on the chromatograms, and identifications are presented in Table 2.

Maximum dissolved-component concentrations are observed after approximately 48 hours. Subsequent water column concentrations decrease from a combination of evaporative losses rrom the water surface and advective processes that ultimately result in mixing with other water masses and dilution. Concomitant (and orders of magnitude greater) evaporative losses of these same components also occur from the surface slick over the same time frame. However, the higher molecular weight aromatics are persistent in the oil, and continued dissolution of $\mathrm{C}_{2}$-substituted naphthalene and alkyl-substituted phen- anthrenes from the surface oil occurs for periods of up to four to seven months. There was no evidence of significant aromatic hydrocarbon dissolution into the water column after 13 months in the wave-tank systems. Presumably, this reflects the diffusion-controlled mass transfer from the oil phase, the limited surface-to-volume ratio of the larger tarballs remaining in the wave-tank system, and the significantly lower water solubilities of the higher molecular weight aromatics that persisted in the tarballs.

Chromatograms from the dispersed- and/or particulate-bound oil phase in the water column are shown in Fig. 5. A time-dependent increase in dispersed oil droplet concentrations appears in the water column. Initial chromatograms of the dispersed oil appeared identical to those from the surface oil samples collected at the same time. As the experiment progressed, however, there was evidence of slightly enhanced evaporation/dis- 

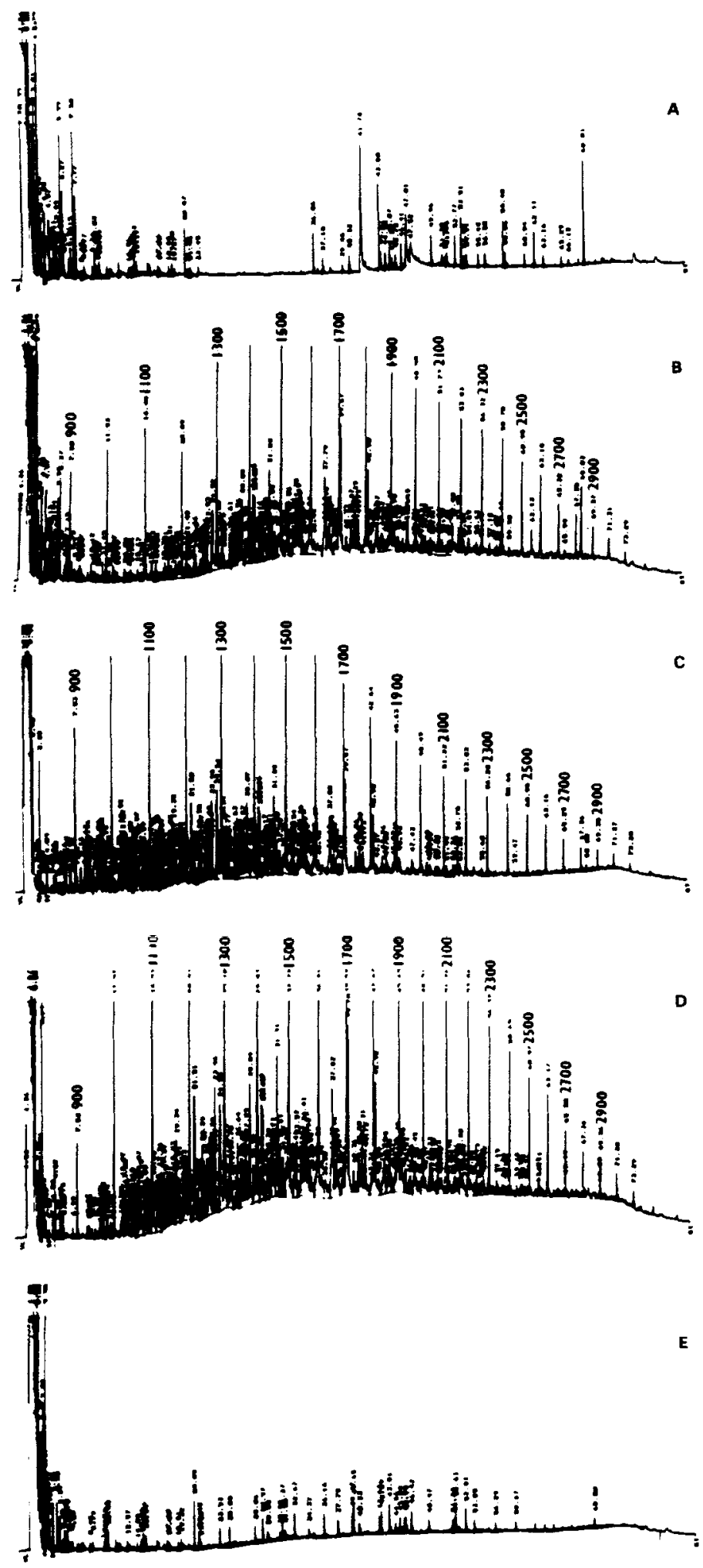

Fig. 5. FID gas

chromatograms of water column filter extracts (dispersed oil droplets) from summer wave-tank experiments at (A) prespill blank, (B) one hour. (C) eight hours. (D) 48 hours, and (E) 12 days after a spill of 16 liters of Prudhoe Bay crude oil. 
solution loss of lighter molecular weight components in the dispersed phase compared to the surface oil slick, particularly in the dispersed oil samples collected between eight and 48 hours. Presumably, this loss resulted from the increased surface-to-volume ratio of the smaller dispersed oil droplets compared to the more continuous surface oil slick. With the increase in viscosity of the surface slick due to the formation of a stable water-in-oil emulsion, the dispersion of oil droplets into the water column became self-limiting after about six to seven days. At the 12-day point (under conditions of constant turbulent mixing in the wave-tank system), there was little evidence of physically dispersed oil droplets in the water column.

\section{Oil-weathering behavior in ice-covered waters}

Oil-weathering in the presence of sea ice is significantly different from that in ice-free waters (Payne et al. 1987a). While many of the same factors (e.g., evaporation, dissolution, dispersion of whole-oil droplets, and water-in-oil emulsification) are important, the presence of the ice itself can inhibit or alter the relative importance of these concomitant, and often competing, processes (NORCOR 1975; Thomas 1980).

\section{Cold room wave-tank experiments}

Laboratory studies measured rates of oil-weathering in the presence of simulated first-year and multiyear sea ice (Payne et al. 1987a). The results of the first-year sea ice studies from laboratory simulations and field observations in the Chukchi Sea are presented here. For these experiments, fresh Prudhoe Bay crude oil was released below a grease-ice and columnar-ice layer under carefully controlled laboratory conditions to simulate a subsurface pipeline release beneath a continuous canopy of first-year ice. Oil-weathering studies were conducted on oil encapsulated in the ice, followed by a simulated "spring thaw" to evaluate surfacing of encapsulated oil through brine channels (Martin 1979). The experiment then studied oil behavior on isolated ice floes and in a slush ice field, and finally through eventual ice breakup and melting into open-ocean conditions. All experiments utilised natural seawater in a 1,870 - liter flow-through wave-tank system constructed in a specially designed cold room at the NOAA Kasitsna Bay laboratory. Artificially generated sea ice simulated Arctic ice conditions (Martin 1979, 1981a, b; Martin \& Kauffman 1981; Weeks \& Weller 1984). The similarities in sea ice between wave-tank simulations and Chukchi Sea field conditions included:

- the temperatures and turbulence conditions for first-year ice growth and type (i.e., frazil, grease, and columnar ice),

- orientation of ice crystal structures (in grease ice and columnar ice) and general ice morphology,

- the salinity profiles in the ice and water column during ice crystal growth and decay, and

- the ambient temperature regimes and infrared solar irradiation characteristic of late spring and early summer conditions for sea ice melting and decay (Payne et al. 1987a).

To simulate under-ice currents and remove excess brine generated during the first-year ice experiments, precooled seawater was introduced into the tank at a flow rate of $11 \mathrm{~min}^{-1}$, resulting in one tank-volume turnover every 1.25 days.

A vertical thermistor array attached to a digital display in an adjacent control room was used to monitor temperatures in the cold room. Fig. 6 shows the time-series temperature profiles of the air, ice and seawater in the wave tank throughout the duration of the oil encapsulation experiment. With continued columnar ice growth under nonturbulent conditions, a significant and stable temperature gradient is generated within the ice. The upper ice surface is at thermal equilibrium with the air temperature, and the lower surface is at equilibrium with the underlying seawater. A chronology of ice formation and oil spill events is presented in Table 4. Salinity data collected during the ice formation experiments are summarized in Table 5. As discussed below, the timing and sequence of ice formation events as well as salinities of seawater, frazil and columnar ice, salt flowers, and brine in the cold room experiments were identical to measurements made on firstyear ice in the Chukchi Sea.

During initial ice formation, the cold room temperature was lowered to $-30^{\circ} \mathrm{C}$, and the incoming seawater was supercooled to $-1.8^{\circ} \mathrm{C}$ in the presence of wave turbulence generated by a hinged, subsurface paddle at one end of the tank. To initiate frazil ice crystal growth on the water 

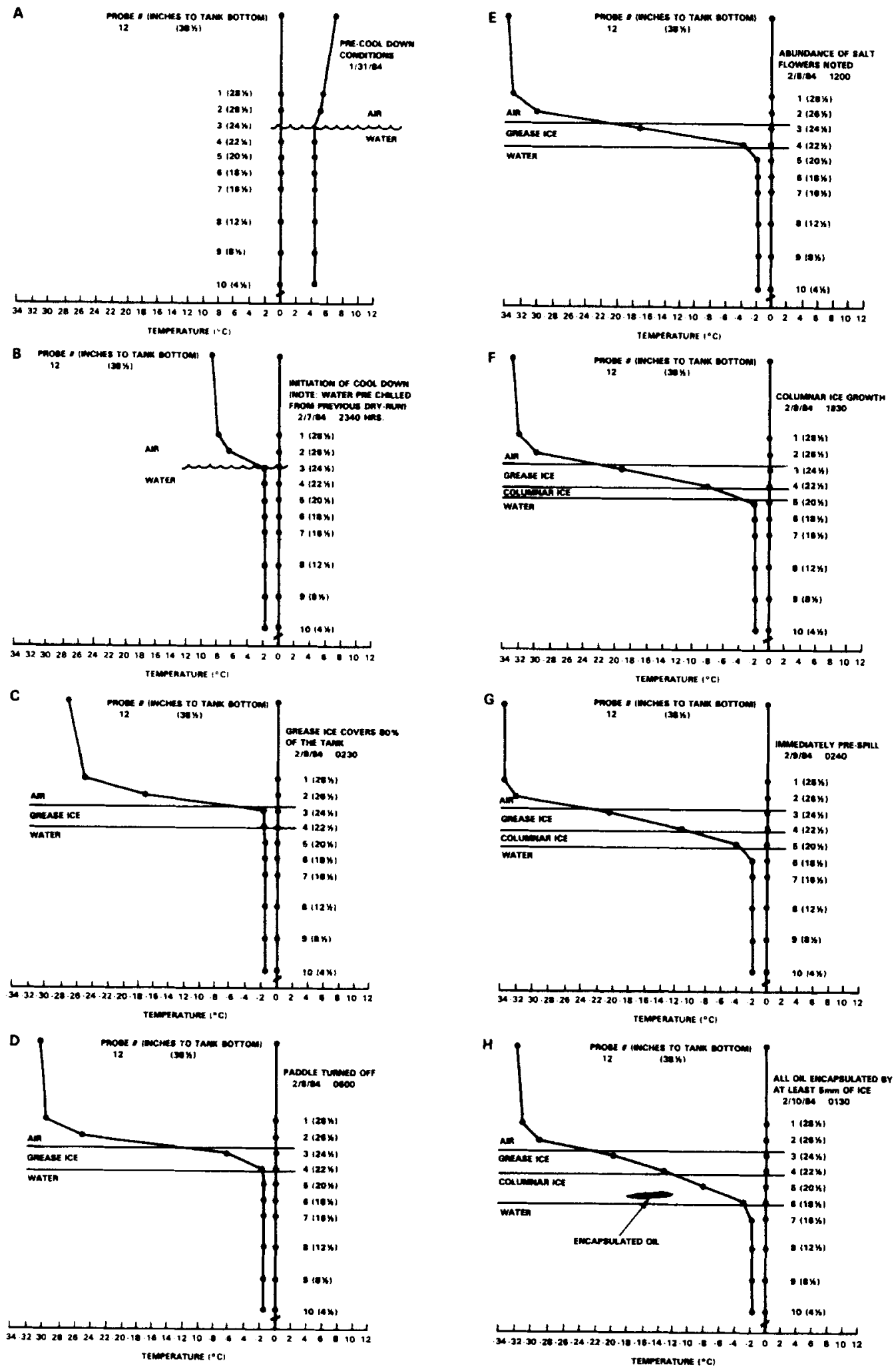
Table 4. Chronology of times and dates of significant events occurring during the oil/ice wave-tank experiment.

\begin{tabular}{|c|c|c|c|}
\hline \multicolumn{2}{|c|}{ Date/Time } & \multirow{2}{*}{$\begin{array}{l}\text { Flow rate } \\
\left(1^{-1} \min \right)\end{array}$} & \multirow{2}{*}{$\begin{array}{l}\text { Significant event description } \\
\text { Initiation of cool down }\end{array}$} \\
\hline $2 / 7 / 84$ & 2340 & & \\
\hline \multirow[t]{8}{*}{$2 / 8 / 84$} & 0130 & - & Grease ice over $2 / 3$ of the tank \\
\hline & 0220 & - & Grease ice $5 \mathrm{~cm}$ thick \\
\hline & 0315 & - & Wave generation terminated \\
\hline & 0330 & 2.4 & Grease ice $7.6 \mathrm{~cm}$ thick - surface skin formed \\
\hline & 0600 & 1.1 & Abundance of salt flowers \\
\hline & 1300 & - & First apperance of columnar ice \\
\hline & 1500 & 1.1 & $7.6 \mathrm{~cm}$ grease ice $+1.3 \mathrm{~cm}$ columnar ice \\
\hline & 1830 & 0.84 & $7.6 \mathrm{~cm}$ grease ice $+2.5 \mathrm{~cm}$ columnar ice \\
\hline \multirow[t]{4}{*}{$2 / 9 / 84$} & 0100 & 0.88 & $7.6 \mathrm{~cm}$ grease ice $+5.0 \mathrm{~cm}$ columnar ice \\
\hline & 0500 & - & 5-liter spil of PB crude complete \\
\hline & 1100 & 0.80 & $7.6 \mathrm{~cm}$ grease ice $+6.4 \mathrm{~cm}$ columnar ice-even with oil pools \\
\hline & 1900 & 0.94 & $7.6 \mathrm{~cm}$ grease ice $+8.9 \mathrm{~cm}$ columnar ice-oil encapsulation complete \\
\hline \multirow[t]{2}{*}{$2 / 10 / 84$} & 0900 & 0.88 & $7.6 \mathrm{~cm}$ grease ice $+11.4 \mathrm{~cm}$ columnar ice \\
\hline & 1630 & - & $7.6 \mathrm{~cm}$ grease ice $+13.3 \mathrm{~cm}$ columnar ice-initial brine channeling \\
\hline $2 / 11 / 84$ & 2100 & 0.76 & $7.6 \mathrm{~cm}$ grease ice $+14.6 \mathrm{~cm}$ columnar ice \\
\hline \multirow[t]{2}{*}{$2 / 13 / 84$} & 1200 & - & Initiation of thaw \\
\hline & 1800 & 0.68 & $7.6 \mathrm{~cm}$ grease ice $+15.9 \mathrm{~cm}$ columnar ice-pools of brine \\
\hline \multirow[t]{2}{*}{$2 / 14 / 84$} & 0430 & - & First oil surfacing \\
\hline & 0630 & 0.67 & $7.6 \mathrm{~cm}$ grease ice $+17.1 \mathrm{~cm}$ columnar ice-maximum ice thickness \\
\hline \multirow[t]{2}{*}{$2 / 15 / 84$} & 1930 & 0.62 & Open leads introduced \\
\hline & 2315 & 0.64 & Ice $14.0 \mathrm{~cm}$ thick $-90 \%$ columnar \\
\hline \multirow[t]{2}{*}{$2 / 16 / 84$} & 0130 & 0.67 & $10 \%$ of the oil has surfaced \\
\hline & 1000 & - & Oil removed for distillation \\
\hline $2 / 18 / 84$ & 1730 & 1.7 & Breakup (wave action initiated) \\
\hline $2 / 20 / 84$ & 1200 & 1.8 & $10.2 \mathrm{~cm}$ grease ice \\
\hline $2 / 22 / 84$ & 1100 & 1.8 & Ice free \\
\hline
\end{tabular}

Table 5. Salinities of various ice types and brines obtained during the oil/sea ice interaction experiment.

\begin{tabular}{|c|c|c|c|c|c|c|}
\hline Sample type & Prefreezeup & $\begin{array}{l}\text { Initial ice } \\
\text { formation } \\
1 / 30 / 84: 2100\end{array}$ & $\begin{array}{l}\text { Sam } \\
\text { Solid ice } \\
1 / 31 / 84: 1230\end{array}$ & $\begin{array}{l}\text { Salinity (ppt) } \\
\text { Mg scenario and } \\
\text { Maximum ice } \\
\text { thickness } \\
2 / 2 / 84: 2200\end{array}$ & $\begin{array}{l}\text { te/time } \\
8 \mathrm{hr} \text { into thaw } \\
2 / 3 / 84: 1900\end{array}$ & $\begin{array}{l}36 \text { hrs after } \\
\text { breakup } \\
2 / 6 / 84: 2100\end{array}$ \\
\hline Seawater & 34.1 & 37.1 & - & 31.1 & - & 30.4 \\
\hline Grease Ice & - & 29.2 & - & - & - & 10.5 \\
\hline Surface Brine & - & - & 85.0 & 76.4 & 12.0 & $\begin{array}{l}47.0 \\
\text { (residing inside } \\
\text { pancake ice) }\end{array}$ \\
\hline Ice@Surface & - & - & 27.7 & 17.5 & 5.8 & $\begin{array}{l}10.5 \\
\text { (rim of pancake } \\
\text { ice) }\end{array}$ \\
\hline 2-in depth & - & - & - & 13.3 & 5.5 & - \\
\hline 4-in depth & - & - & - & 12.5 & 9.5 & - \\
\hline 6-in depth & - & - & - & 14.2 & - & - \\
\hline
\end{tabular}

Fig. 6. Temperature/depth profiles obtained during oil encapsulation experiment (see Table 4 for chronology of events in cold room experiments). 
surface, wave turbulence was temporarily stopped, and under the influence of a 3-5-knot wind, frazil ice crystal growth appeared within 12 minutes. Wave turbulence was reintroduced to drive the frazil ice crystals into the water column and encourage the formation of grease ice and slush ice (Armstrong et al. 1966; Martin 1981b). Frazil ice crystals were observed throughout the $90-\mathrm{cm}$ water column, and within three hours of the initial frazil ice formation, a $5-\mathrm{cm}$ layer of grease ice covered $80 \%$ of the tank surface. When the slush/grease ice layer became so thick that almost complete wave dampening occurred (Martin 1981b; Bauer \& Martin 1983), the subsurface paddle was stopped. In the absence of wave turbulence, a $4-\mathrm{cm}$ layer of columnar ice (Martin 1979) grew over the next 20-21 hours below the grease ice layer. Observations of ice growth and columnar ice crystal structure orientation were obtained throughout this period via windows installed on both sides of the wave tank.

Table 6. Salinities of various ice types obtained during Chukchi Sea ice investigations.

\begin{tabular}{llr}
\hline Field site no. & Depth or description & Salinity (ppt) \\
\hline C-1 & $25.4 \mathrm{~cm}$ & 11.5 \\
C-1 & $30.5 \mathrm{~cm}$ & 7.5 \\
C-2 & $25.4 \mathrm{~cm}$ & 16.1 \\
C-2 & $45.7 \mathrm{~cm}$ & 15.0 \\
C-2 & Water & 28.7 \\
C-3 & Surface brine & 61.9 \\
C-3 & $7.6 \mathrm{~cm}$ & 14.3 \\
C-3 & $30.5 \mathrm{~cm}$ & 15.4 \\
C-4 & $61.0 \mathrm{~cm}$ & 12.5 \\
C-5 & Water & 29.1 \\
C-6 & $5.0 \mathrm{~cm}$ & 21.5 \\
C-6 & $61.0 \mathrm{~cm}$ & 8.0 \\
C-6 & $30.5 \mathrm{~cm}$ & 8.3 \\
C-6 & $91.4 \mathrm{~cm}$ & 12.5 \\
C-7 & $15.2 \mathrm{~cm}$ & 11.0 \\
C-7 & $20.3 \mathrm{~cm}$ & 8.3 \\
C-7 & $30.5 \mathrm{~cm}$ & 9.0 \\
C-7 & $61.0 \mathrm{~cm}$ & 10.2 \\
D-2 & Overflow 1 & 18.0 \\
D-2 & Overflow 2 & 17.5 \\
D-3 & Columnar ice-25.4 cm & 3.5 \\
D-6 & Surface ice & 21.0 \\
New lead & Thin new ice & 45.3 \\
New lead & Thick new ice & 14.1 \\
New lead & Columnar ice & 4.7 \\
\hline
\end{tabular}

${ }^{a}$ Site no. designated by field study according to Hachmeister et al. (1985).

- Overflow ice samples obtained at two different locations at site D-2.

'Not an official field site.
As the ice surface congealed, a slight upward bowing of the ice canopy appeared due to pressure from the sides of the tank. Similar bowing and deformation of congelation ice due to pressure from adjacent ice floes and ridges were observed in refrozen leads studied in the Chukchi Sea. Also, as the ice canopy in the wave tank solidified, $1-2-\mathrm{cm}$ salt flowers formed from brine exuded from the freezing ice as described by Martin (1979). Salt flowers almost identical to these (in

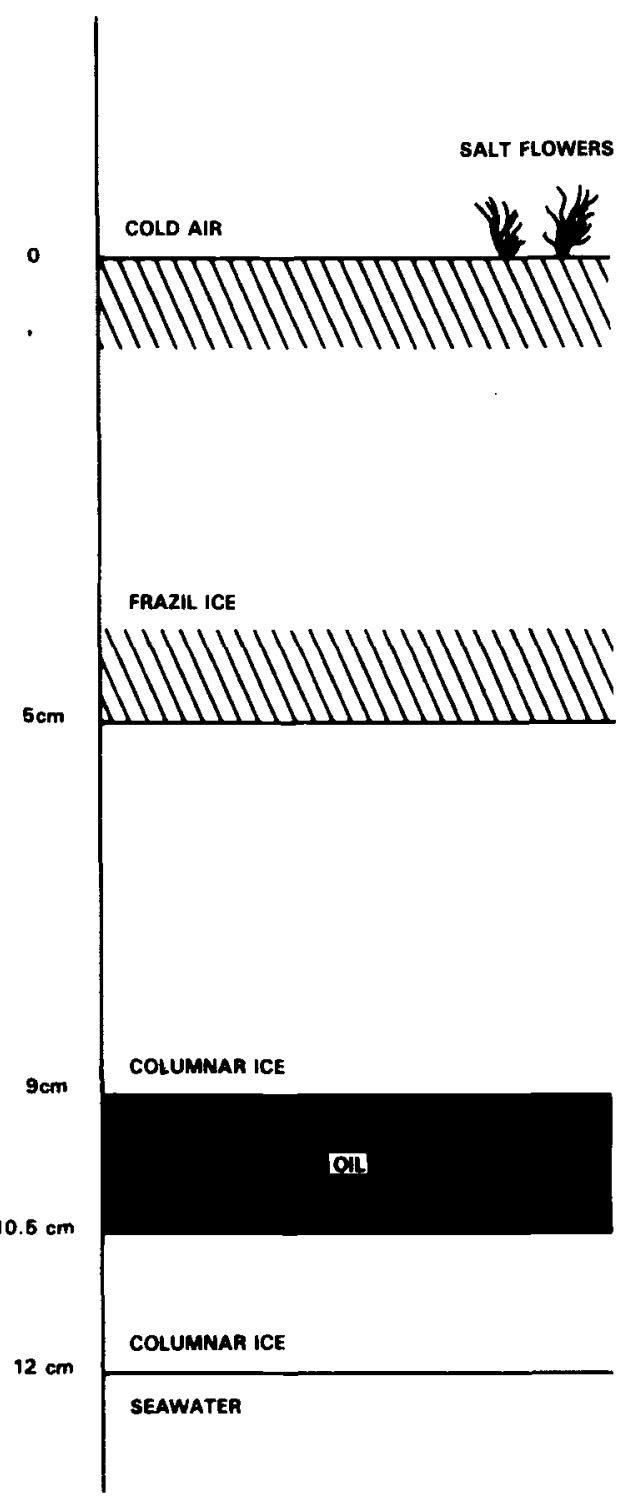

Fig. 7. Schematic diagram of desired ice-oil configuration after encapsulation. 

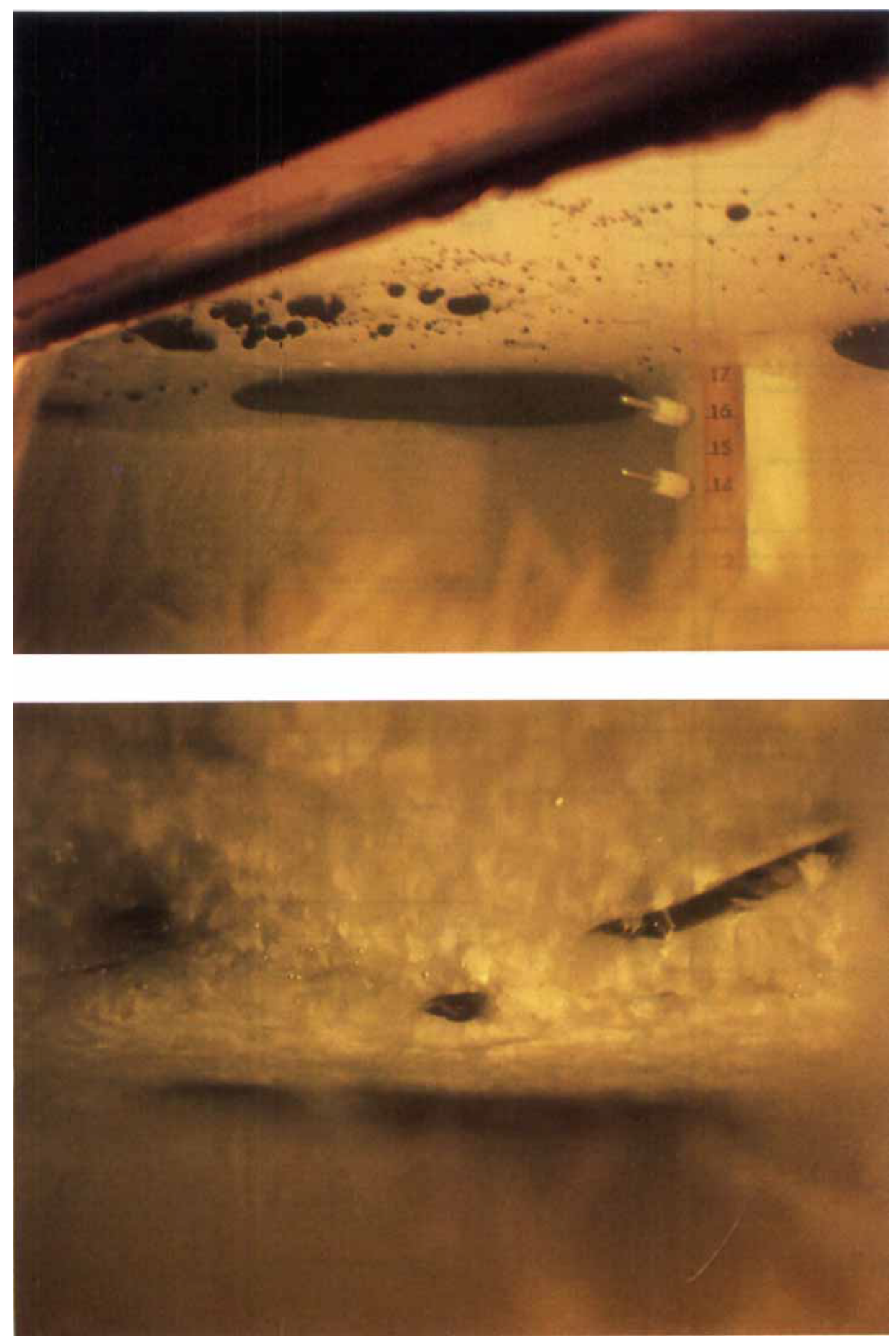

Fig. 8. Subsurface photograph of oil pooling in under-ice depressions just after the spill (note the thermistor array in the background of the figure)

Fig. 9. Subsurface photograph of oil pool trapped under ice surface after partial encapsulation by 5-6 mm of columnar ice. Note limited horizontal ice platelet growth on underside of oil surface in the foreground. 

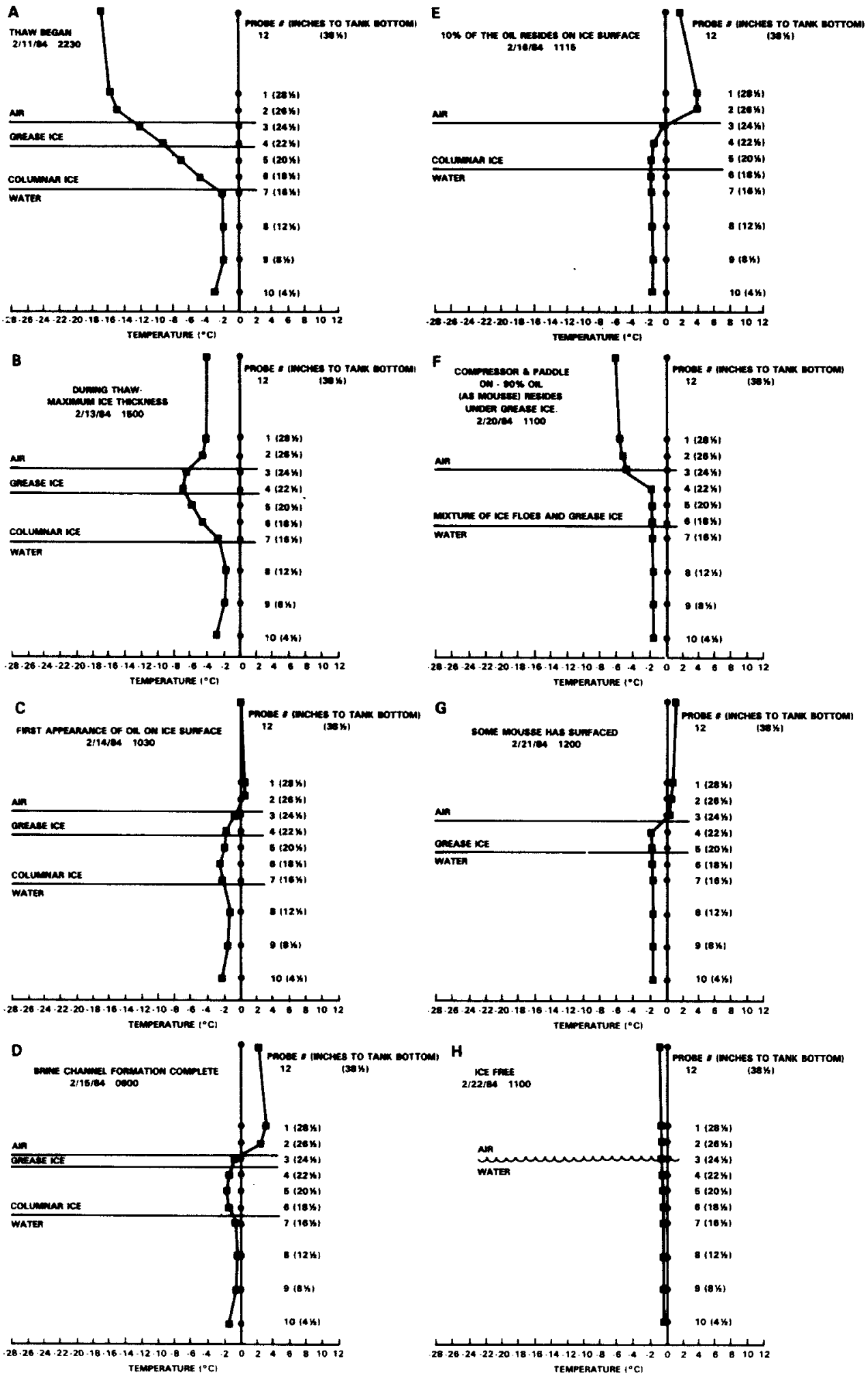
size, salt content, and surface distribution) were observed in the Chukchi Sea. The field salinity measurements of sea ice, brine pools, salt flowers and columnar ice agree closely with data obtained from the cold room and wave-tank system (Tables 5 and 6). Prefreeze water column salinities in the wave tank were 34 parts per thousand (ppt), and an increase in salinity up to $37 \mathrm{ppt}$ was observed initially after freezing. Surface brine and salt flowers had salinities of $85 \mathrm{ppt}$ in the wave tank, whereas the ice had salinities in the 12-14 ppt range. After the thaw cycle and brine channel drainage, wave tank ice salinities were lower, ranging from 5-10 ppt. Salinities of samples collected in the Chukchi Sea were in the same range, with surface brine having a salinity of $65 \mathrm{ppt}$, congelation ice ranging from $12-15 \mathrm{ppt}$, and columnar ice exhibiting values from 5-8 ppt.

In Fig. 7, a profile of the experimental ice/ oil configuration for the simulated subsurface oil discharge under first-year ice is shown schematically. When the ice layer in the tank consisted of 5-6 cm of congealed surface grease ice over 4$6 \mathrm{~cm}$ of columnar ice, 5 liters of fresh Prudhoe Bay crude oil were introduced below the ice layer through a Teflon tube. Oil droplets congealed immediately underneath the ice, and some oil pooling was observed in under-ice depressions (generated by placing styrofoam blocks on the upper ice surface to simulate insulation from snow drifts, Barnes et al. 1979). Fig. 8 shows one such pool of oil adjacent to the underwater thermistor array; the figure also illustrates the formation of 1-2-cm oil droplets under the ice layer. Within 4 5 hours, a 1-2-mm layer of horizontal ice platelets had begun to cover the lower oil surface. After 23 hours, the spilled oil was almost totally encapsulated by a $5-\mathrm{mm}$ layer of vertical columnar ice crystals growing below (Fig. 9). An additional $12 \mathrm{~cm}$ of columnar ice was allowed to grow beneath the oil lens over a 4-day period, and the spill remained entrapped within the columnar ice until a thaw cycle was initiated. Ice thicknesses were constrained both by the refrigeration capabilities of the cold room (minimum temperature $-38^{\circ} \mathrm{C}$ ) and the flow-through seawater system (Payne et al. 1987a).

During and after oil encapsulation within the ice, the flow-through seawater system removed all dissolved components and any dispersed oil droplets. Water column measurements of dissolved and dispersed hydrocarbons were completed over this four-day period to ensure that the system had returned to near "background" levels before initiation of the thaw

To simulate spring thaw conditions (Martin 1979 ), the cold room temperature was maintained at -8 to $-12^{\circ} \mathrm{C}$, and two banks of infrared quartz heaters (set on the lowest settings) were directed at the ice surface from a distance of 1 meter, simulating low-angle solar infrared radiation. A significant temperature gradient was observed in the frozen grease ice and columnar ice canopy, and this was particularly apparent just before initiation of the thaw cycle when the ice was $15-17 \mathrm{~cm}$ thick (Fig. 10). Within 48 hours after initiation of the thaw cycle, the ice temperature gradient began to break down. This resulted in partial melting of the surface grease ice layer and the formation of standing pools of brine (from dissolution of salt flowers) on top of the ice. Some drainage of these pools was noted through brine channels (introduced into the ice canopy during the freezing cycle), and upward density-mediated oil migration through the drained brine channels could be observed both from the ice surface and from encapsulated oil lenses adjacent to the tank windows. Brine drainage through the ice canopy also led to advective transport of dense, cold brine to the bottom of the tank as manifest by the nearbottom decrease in seawater temperatures (to $<-3^{\circ} \mathrm{C}$ ) before the introduction of wave turbulence and water column mixing (Fig. 10A-D).

\section{Quantitation of rates of brine channel drainage and oil migration}

To study brine channel drainage and oil densitymediated migration in a floating ice patch, a 71 . $\mathrm{cm}$ test floe was cut in the center of the ice at the initiation of the thawing period. This test floe was left in place, but its buoyancy was not restrained by the surrounding fast-ice layers held in place by the tank walls. With this circular test floe, brine channel drainage and upward oil migration rates could be measured on ice behaving under natural buoyancy conditions.

Fig. 10. Temperature/depth profiles obtained during thaw cycle and ice breakup after oil encapsulation (see Table 4 for chronology of events in cold room experiments). 
Table 7. Experimentally determined oil migration rates.

\begin{tabular}{rcccc}
\hline $\begin{array}{l}\text { Elapsed Time } \\
(\mathrm{hr})\end{array}$ & $\begin{array}{l}\text { Area } \\
\left(\mathrm{cm}^{2}\right)\end{array}$ & $\begin{array}{l}\text { Thickness } \\
(\mathrm{cm})\end{array}$ & $\begin{array}{l}\text { Volume } \\
(\mathrm{ml})\end{array}$ & $\begin{array}{l}\text { Average rate } \\
\left(\mathrm{ml} \mathrm{hr}^{-1}\right)\end{array}$ \\
\hline 4.3 & 9.1 & 0.05 & 0.45 & 0.11 \\
10.2 & 1.4 & 0.30 & 0.87 & 0.09 \\
16.8 & 52.8 & 0.22 & 11.9 & 0.71 \\
25.0 & 279 & 0.46 & 129 & 5.2 \\
35.8 & 269 & 0.83 & 224 & 6.2 \\
88.0 & 1.260 & 0.30 & 378 & 4.3 \\
\hline
\end{tabular}

Within four hours after the test floe had been cut out of the fast-ice surface, the oil began to surface through the circular test floe. Estimates of oil flow rates through the brine channels were derived from the amount of surface oil measured (area $\times$ thickness) on the test floe over time. Time-series photographs documented the flowrate changes to provide the volume and rate estimates listed in Table 7. The data in Table 7 were used to evaluate the brine channel migration predictions by Cox et al. (1981), where the minimum brine channel diameter that would allow oil migration $\left(d_{i}\right)$ was given by

$d_{i}=\frac{4 \sigma_{o w}}{\delta} \cdot \frac{\cos \alpha}{\left(\rho_{w}-\rho_{o}\right) g}$

where, for the experimental spill, $\sigma_{o w}$ is the oil/ water interfacial tension $\left(24.2 \mathrm{~g} \mathrm{~s}^{-2}\right), \alpha$ is angle of contact $(0), \delta$ is the oil lens thickness $(2.5 \mathrm{~cm})$ under the ice, $\rho_{w}$ is the water density $\left(1.03 \mathrm{~g} \mathrm{~cm}^{-3}\right), \rho_{\mathrm{o}}$ is the oil density $\left(0.92 \mathrm{~g} \mathrm{~cm}^{-3}\right)$, and $\mathrm{g}$ is the gravitational constant $\left(980 \mathrm{~cm} \mathrm{~s}^{-2}\right)$. Using these values to solve for $d_{i}$ indicates a minimum brine channel diameter of $3.6 \mathrm{~mm}$, which agrees with observations made in the wave tank and brine channel diameters from published oil spill studies (Martin 1979).

The rise rate velocity is given by

$\mu_{\mathrm{z}}=\frac{\left(\rho_{w}-\rho_{\mathrm{o}}\right) g \delta d^{2}}{32 \mathrm{~L} \mu}$

where $\rho_{w}, \rho_{0}, g$, and $\delta$ are as before, $d$ is the brine channel diameter $(0.36 \mathrm{~cm}), \mathrm{L}$ is the ice thickness $(5.7 \mathrm{~cm})$, and $\mu$ is the oil viscosity $\left(5.5 \mathrm{~g} \mathrm{~cm} \mathrm{~s}^{-1}\right)$. Solving for $\mu_{\mathrm{z}}$, a rise rate of $0.35 \mathrm{~mm} \mathrm{~s}^{-1}$ was determined. This value is lower by a factor of two than the rise rate of $0.7 \mathrm{~mm} \mathrm{~s}^{-1}$ determined experimentally by Martin (1979). However, slight changes in in situ oil viscosity (while still in the ice) or even a slight (1.4-fold) difference in brine channel diameter could result in a factor of two change in $\mu_{z}$. Viscosity limitations to flow may be particularly important in this regard because viscosity is temperature dependent. No considerations for the temperature gradients measured within the ice have been incorporated in existing models.

Finally, the volume flow rate to the surface can be expressed by

$V=\frac{\pi d^{2}}{4} \mu_{z} N^{\prime} A$

where $d$ is as before, $\mu_{z}$ is the rise rate velocity $\left(0.035 \mathrm{~cm} \mathrm{~s}^{-1}\right), \mathrm{N}^{\prime}$ is the number of brine channels per area $\left(0.01 \mathrm{~cm}^{-2}\right)$ and $A$ is the area of the spill $\left(209 \mathrm{~cm}^{2}\right)$. The value of $\mathrm{V}$ (using experimental data) indicates that the volume of oil deposited on the surface as a function of time should be approximately $27 \mathrm{ml} \mathrm{hr}^{-1}$. This value is high compared to the experimental values (Table 7). Other factors that may affect the differences between calculated and observed flow rates include

- the temperature gradient within the ice,

- the depth of the oil pool in the ice,

- the rate of temperature increase in the laboratory,

- the relative thinness $(<10 \mathrm{~cm})$ of the laboratory ice,

- the initial trapping of the oil lens in columnar ice $4 \mathrm{~cm}$ below a $5-\mathrm{cm}$ canopy of refrozen grease ice,

- indeterminate number of brine channels/unit area in the laboratory and field studies,

- the influence of entrapped oil on changes in the ice albedo immediately above,

- the influence of the oil after it has surfaced with additional ice ablation and melting.

Additional model refinement of the oil migration in brine channels is warranted sub- 
Fig. 11. FID-capillary chromatograms of oilweathering in the presence of sea ice. A. Fresh Prudhoe Bay crude oil. B. Encapsulated oil. C. Bulk oil from a 5-mm deep pool exposed for three hours.
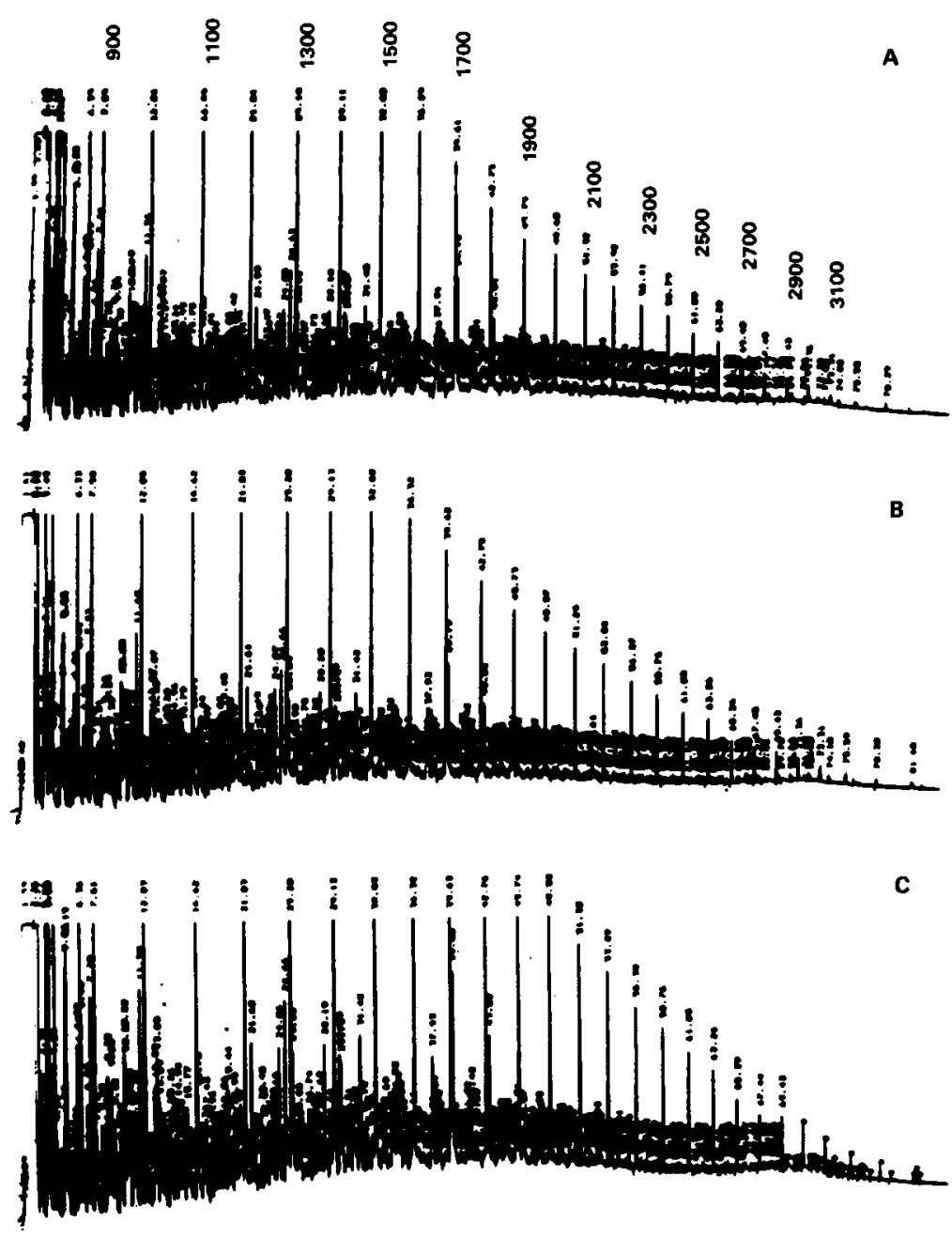

sequent to this first comparison of measured data with predictions based on Cox's approach.

\section{Oil phase physical and chemical properties}

changes during weathering in the presence of decaying first-year ice

Approximately six hours after the first brine channel oil migration was noted in the circular test floe, the oil had pooled in approximately five areas. The largest oil pool was approximately $1 \mathrm{~cm}$ in diameter. Within 24 hours, several oil pools up to $5 \mathrm{~cm}$ long were noted on the test floe. With increased absorption of infrared energy, these pools enhanced oil spreading and ice melting, which is indicated by the temperature profiles (Fig, 10). Within three more days an estimated $90 \%$ of the oil was present on the ice/ water surface. Chromatograms of the oil, both immediately after it was released from ice encapsulation and after it had been exposed at the water surface for three hours, are shown in Fig. 11. Qualitatively, the chromatographic profiles appear identical, indicating little (if any) evaporative loss.

In oil sampled from several other locations, however, there was evidence of selective loss of lower molecular weight components as the oil migrated through the brine channels. Fig. 12 presents chromatograms obtained on encapsulated oil, an oil sample obtained from a 3-mm diameter brine channel below the ice/air interface, and a sample from a $5-\mathrm{mm}$ deep oil pool that had migrated through a brine channel and flowed out 

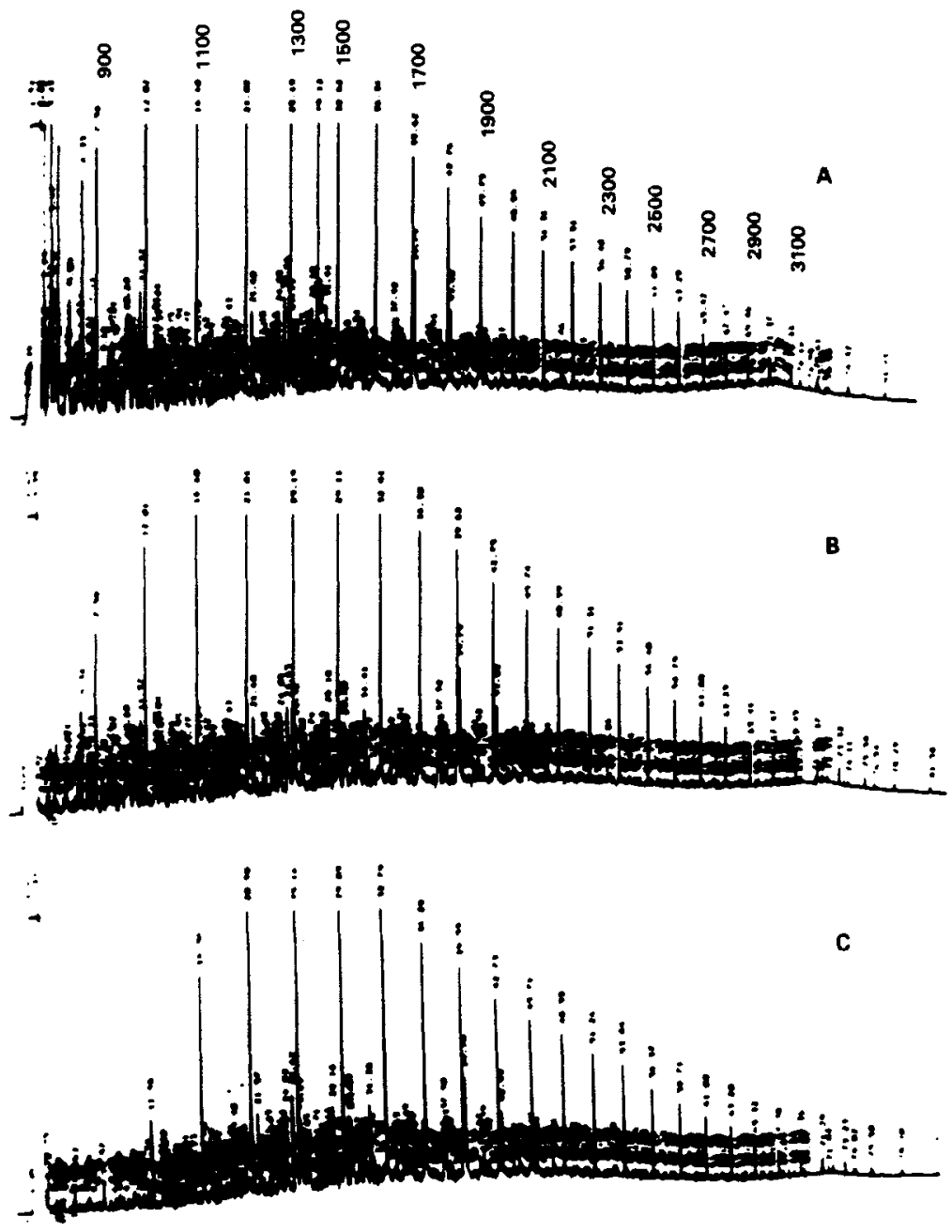

Fig. 12. FID-capillary gas chromatograms of wave ice tank oil samples. A. Fully encapsulated by ice. B. During upward brine channel migration. $C$. Exposed on the ice surface for 48 hours. over the ice surface. Even at a depth of $3-5 \mathrm{~cm}$ into the brine channel, some evaporation loss of lower molecular weight components below $n-C_{9}$ occurred (Fig. 12B). After surfacing and being exposed for 48 hours, the thicker whole-oil mass showed loss of compounds below $n-C_{11}$ (BP $304^{\circ} \mathrm{F}$ ) (Fig. 12C). Such evaporative loss has significant implications for attempted in situ combustion of oil on ice; these more volatile components are important for ignition and flame propagation. With the oil in a thicker pool on the ice surface, diffusion-controlled evaporation is believed to predominate over other simultaneous weathering processes (see discussion below).

The apparent loss of volatile lower molecular weight alkanes from the oil that is still trapped in brine channels is not believed to significantly affect the overall mass balance of a spill. Evaporation behavior is believed to be diffusion-controlled in the oil phase due to the lack of physical mixing in the oil phase and the high viscosity (550 centipoise) of oil at the ice temperatures during brine channel migration. Therefore, selective component evaporation would affect only the uppermost portions of oil in the brine channels. The release of the majority of the volatile components from the trapped oil would be retarded until the bulk of the oil reached the surface of the ice or water. Thus, little evaporative loss appeared in the bulk oil sample collected from the ice surface (Fig. 11).

To examine the effects of turbulence on oil weathering in the presence of grease ice and test ice floes, rotten ice was cut and broken physically 
into $60-80-\mathrm{cm}$ diameter floes three days after the induced 'thaw' was initiated (Table 4). The paddle system then was activated to generate $6-10-\mathrm{cm}$ waves in the broken ice field. The grinding of the larger ice floes against one another and the microscale turbulence (effected by the pumping grease and slush ice crystals between the major floes) significantly enhanced the formation of a stable water-in-oil emulsion. The pumping action created by the wave oscillations in the slush ice field also caused the oil to collect on the ice floes and around the rims on the pans (due to accumulating slush ice) as described by Martin (1981a). Subsurface observations and water sampling revealed elevated levels of dispersed oil in the water column resulting from this small-scale turbulence. Oil droplet dispersion into the water column quickly became self-limiting, however, due to the rapid (within four hours) formation of a stable water-in-oil emulsion and increase in oil viscosity.

The water-in-oil emulsion formed in the tank was not neutrally buoyant compared to the ice; its density $\left(0.982 \mathrm{~g} \mathrm{~m}^{-1}\right)$ enabled the larger emulsified oil patches to reside below the surface grease ice. (In the field, aerial tracking of such tarballs $(5-8 \mathrm{~cm})$ thus would be difficult.) With continued agitation and eventual melting of the grease ice (Table 4), the water-in-oil mixture eventually surfaced in the open water between the ice floes. Similar observations made during the KURDISTAN oil spill (No. 6 fuel oil spilled on ice-covered waters in Cabot Strait) revealed an oil density greater than the grease ice density and only slightly less dense than the water (C-Core 1975). As a result, the oil often resided beneath the grease ice, similar to the behavior observed in our studies. In the KURDISTAN spill as much as $50 \%$ of the oil was estimated to be entrained in the brash ice to a depth of one metre.

The rheological properties data (Tables 8-10) for the emulsified oil generated in the cold room/ wave-tank experiments indicated that the oil/ water interfacial surface tension in the emulsified oil remained at approximately $25-26$ dynes $\mathrm{cm}^{-1}$ during the experiment. The oil/air interfacial surface tension also did not change during the emulsification process. Comparisons between changes in the rheological properties of mousse generated under open ocean/ice-free conditions and those in mousse in the presence of artificial first-year ice can be made by examining the data in Fig. 13. A smooth decrease in oil/water interfacial surface tension (from 27 to 13 dynes $\mathrm{cm}^{-1}$ ) was observed

Table 8. Interfacial tension (oil/water) and surface tension (oil/air) obtained at various times during the oil/sea ice interaction experiment.

\begin{tabular}{llc}
\hline Sample state & $\begin{array}{c}\text { Oil/water interfacial } \\
\text { tension }\left(\text { dynes } \mathrm{cm}^{-1}\right)\end{array}$ & $\begin{array}{l}\text { Oil/air surface } \\
\text { tension }\left(\text { dynes } \mathrm{cm}^{-1}\right)\end{array}$ \\
\hline $\begin{array}{l}\text { Fresh crude (prespill) } \\
\left.\text { Oil approaching the ice surface through brine channels (oil temp. @1.8 }{ }^{\circ} \mathrm{C}\right)\end{array}$ & 26.2 & 33.4 \\
$\quad$ ambient measurement & 24.2 & 36.8 \\
Pooled oil after surfacing & 23.4 & 34.7 \\
Mousse-4 hours after breakup & 25.8 & 35.9 \\
Mousse-12 hours after breakup & 27.3 & 35.2 \\
Mousse-4 days after breakup & 26.7 & 36.7 \\
\hline
\end{tabular}

"Except where noted, all measurements were obtained after sample equilibration at room temperature.

Table 9. Water content (percent by weight) in oil weathered in the presence of sea ice.

\begin{tabular}{llc}
\hline Sample description & Sampling time/date & Water content ${ }^{\mathrm{a}}$ (percent) \\
\hline Fresh Prudhoe Bay crude & Prespill & $<0.01$ \\
Oil encapsulated by ice & $06002 / 16 / 84$ & 4.3 \\
Freshly exposed oil & $11002 / 16 / 84$ & 7.4 \\
Mousse-4 hours after breakup & $16002 / 18 / 84$ & 64 \\
Mousse-11 hours after breakup & $22302 / 18 / 84$ & 65 \\
Mousse-3 days after breakup & $13302 / 21 / 84$ & 64 \\
Mousse-4 days after breakup & $22002 / 22 / 84$ & 66 \\
\hline
\end{tabular}

\footnotetext{
- Water content determined by Karl Fischer titration or ASTM 1796.
} 
Table 10. Oil viscosities at various times and temperatures obtained during the oil/sea ice interaction experiment.

\begin{tabular}{lcr}
\hline Sample state & $\begin{array}{l}\text { Oil temperature } \\
\left({ }^{\circ} \mathrm{C}\right)^{3}\end{array}$ & $\begin{array}{c}\text { Viscosity } \\
\text { (centipoise) }\end{array}$ \\
\hline Fresh crude (prespill) & 20.0 & 50 \\
Oil approaching the ice surface through brine channels & 1.0 & 550 \\
Oil on ice surface ( -10\% remaining in the ice) & 2.1 & 500 \\
Weathering oil-11 hours after breakup & -2.0 & 25.000 \\
Weathering oil-11 hours after breakup & 38 & 1.100 \\
Mousse-36 hours after breakup & -2.5 & 30,000 \\
Mousse-36 hours after breakup & 38 & 1,200 \\
Mousse-4 days after breakup & 1.0 & 30,000 \\
Mousse-4 days after breakup & 38 & 1.400
\end{tabular}

a Except for $38^{\circ} \mathrm{C}$ cases, viscositics were taken at experimental ambient temperatures.
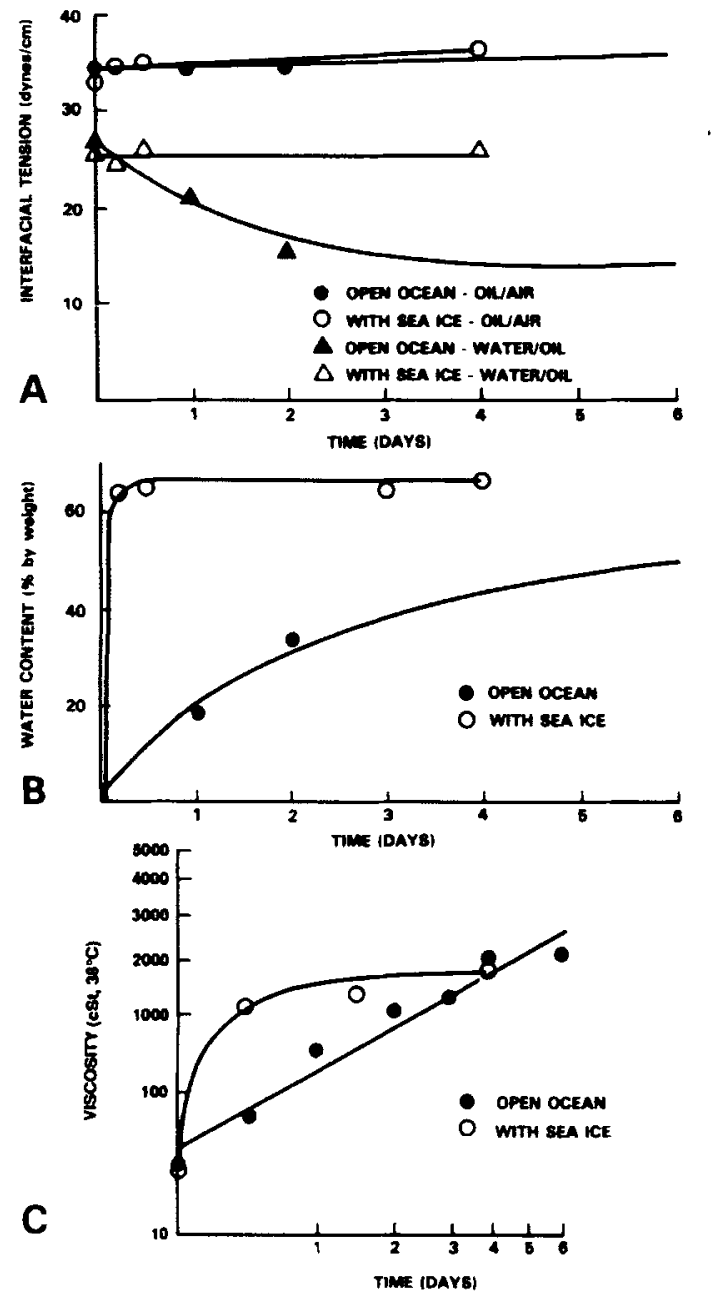

Fig. 13. Comparison of weathered oil rheological properties between open-ocean conditions and with sea ice present $A$. Interfacial tension. B. Water incorporation. C. Viscosity (at $38^{\circ} \mathrm{C}$ ). during open-ocean weathering, whereas this value was constant for mousse formation in the presence of the slush ice field in the decaying first-year ice. The oil/air interfacial surface tension remained relatively constant for both open-ocean and oil/ ice weathering conditions. Thus, in the presence of an undulating slush ice field, a stable water-inoil emulsion was generated without the formation of oxidation products (Payne \& Phillips 1985b) and the change in oil/water interfacial surface tension noted under open-ocean weathering (Payne et al. 1984).

For comparison, water content in mousse after ice breakup and initiation of wave turbulence reached $64 \%$ within four hours (Table 9 ), whereas water buildup in mousse did not occur in openocean test tank studies for eight to 12 days under summer conditions. Also, in the open-ocean conditions the increase in water content followed a smooth curve rather than the rapid buildup noted in the presence of the decaying first-year ice. In contrast, rotting multiyear ice in cold room wavetank experiments had less tendency to produce a slush ice matrix during breakup and melting, and formation of a stable water-in-oil emulsion occurred over a relatively longer time period, approaching that of ice-free winter conditions (Payne et al. 1984, 1987a).

Large increases in viscosity were measured in the laboratory-generated water-in-oil emulsions (Table 10). As it surfaced through the brine channels, fresh oil had a viscosity of 550 centipoise at $1^{\circ} \mathrm{C}$; whereas mousse formed four hours after the onset of turbulence exhibited a viscosity of 25,000 centipoise at $-2^{\circ} \mathrm{C}$. When this sample was warmed in the laboratory to $38^{\circ} \mathrm{C}\left(100^{\circ} \mathrm{F}\right)$ for standard viscosity testing, a value of 1,100 
centipoise was obtained. For comparison, the viscosities of mousse formed in open-ocean oilweathering experiments approached 1,100 centipoise (at $38^{\circ} \mathrm{C}$ ) only after $3-4$ days in summer subarctic conditions (Payne et al. 1984). Maximum oil viscosities in the oil/ice experiments approached 30,000 centipoise at ambient $\left(-2.5^{\circ} \mathrm{C}\right)$ temperatures and 1,400 centipoise at $38^{\circ} \mathrm{C}$ after four days.

Water content and viscosity of water-in-oil emulsions generated in ice-covered waters impact the efficiency of cleanup strategies. In situ combustion is adversely affected by the presence of water-in-oil emulsions. The maximum water content for effective burning of emulsions is $\sim 70 \%$ by volume for lighter and medium crudes and $30 \%$ by volume for heavy crudes (Twardus 1980 ). Thus, if in situ combustion is planned for combating oil spills in ice-covered waters, ignition should be attempted soon after encapsulated oil has reached the ice surface before wave-induced turbulence in the presence of broken ice floes and grease ice can lead to water-in-oil emulsification. Likewise, pumping emulsified oils with in situ viscosities of $20,000-30,000$ centipoise would be impossible without warming, and oil spill dispersants would be completely ineffective (NAS 1989).

Very few time-series changes in hydrocarbon composition occurred with the formation of stable water-in-oil emulsions in the cold room wavetank experiments. Some evaporative weathering of the emulsion occurred; however, unlike oil trapped on top of the ice floes by lead-matrix pumping, the water-in-oil emulsions contained most of the lower molecular weight components of fresher crudes (Fig. 14). The rapid generation of stable water-in-oil emulsions occurred before

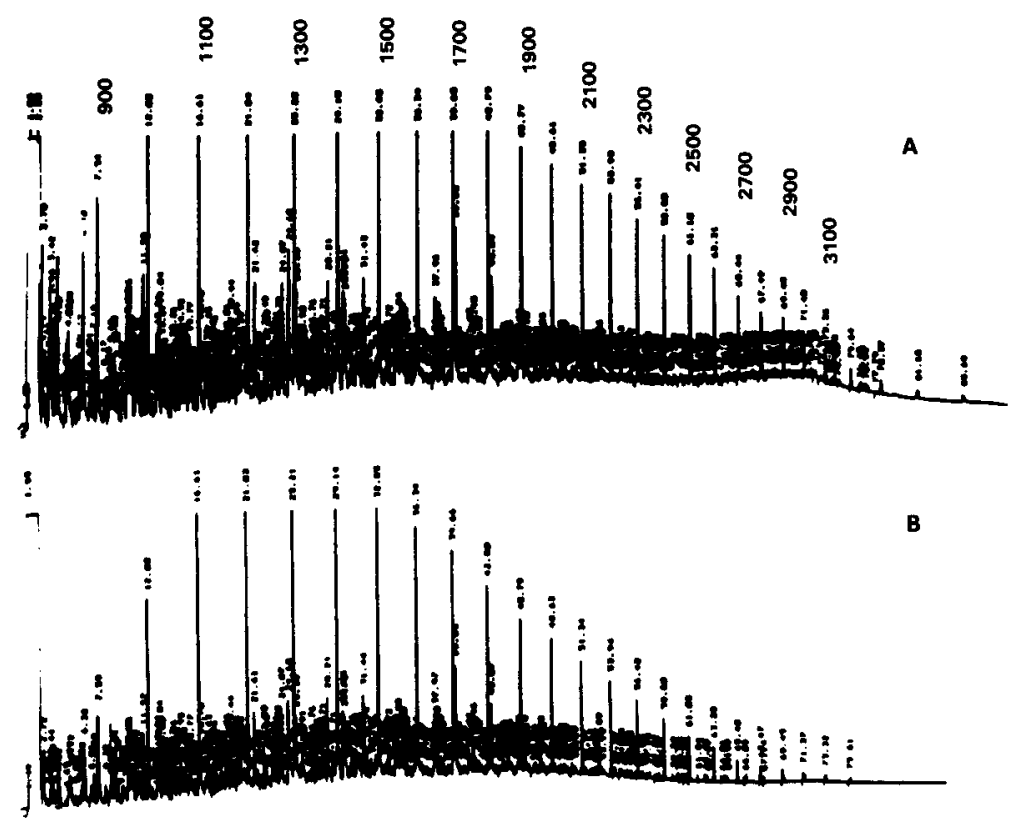

Fig. 14. FID-capillary gas chromatograms of emulsified oil weathering in a broken ice field $(\mathrm{A})$ 1-cm deep oil pool exposed on ice surface for 32 hours, (B) 1-cm deep oil pool exposed on ice surface for 57 hours, and (C) subsurface mousse obtained two days after ice breakup.

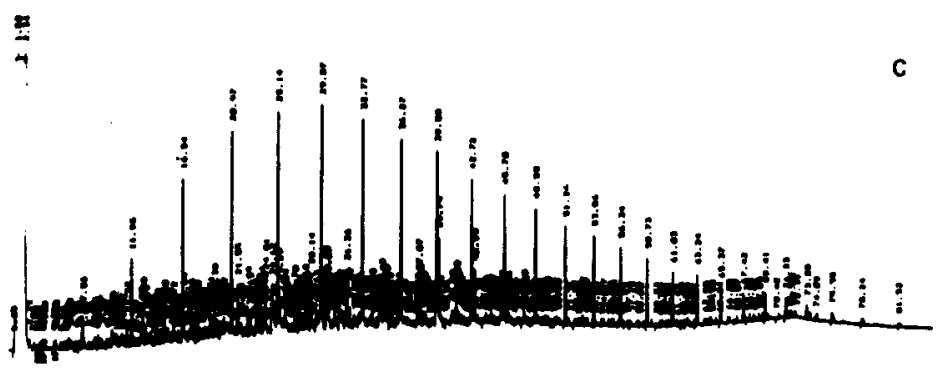


evaporation and dissolution weathering removed lower molecular weight components from oil in the water column. Under these conditions, the resultant mousse contained many of the more toxic lower molecular weight alkyl-substituted one- and two-ring aromatic compounds. Given the emulsion's high in situ viscosity, subsequent loss of these components would only be by slow, oil-phase diffusion-controlled evaporation and dissolution processes. Relative to concentrations in fresh oil, losses of $\mathrm{n}$-alkanes below $\mathrm{n}-\mathrm{C}_{9}$ occurred in exposed and emulsified oil. However, during open-ocean oil weathering with Prudhoe Bay crude oil, comparable stable water-in-oil
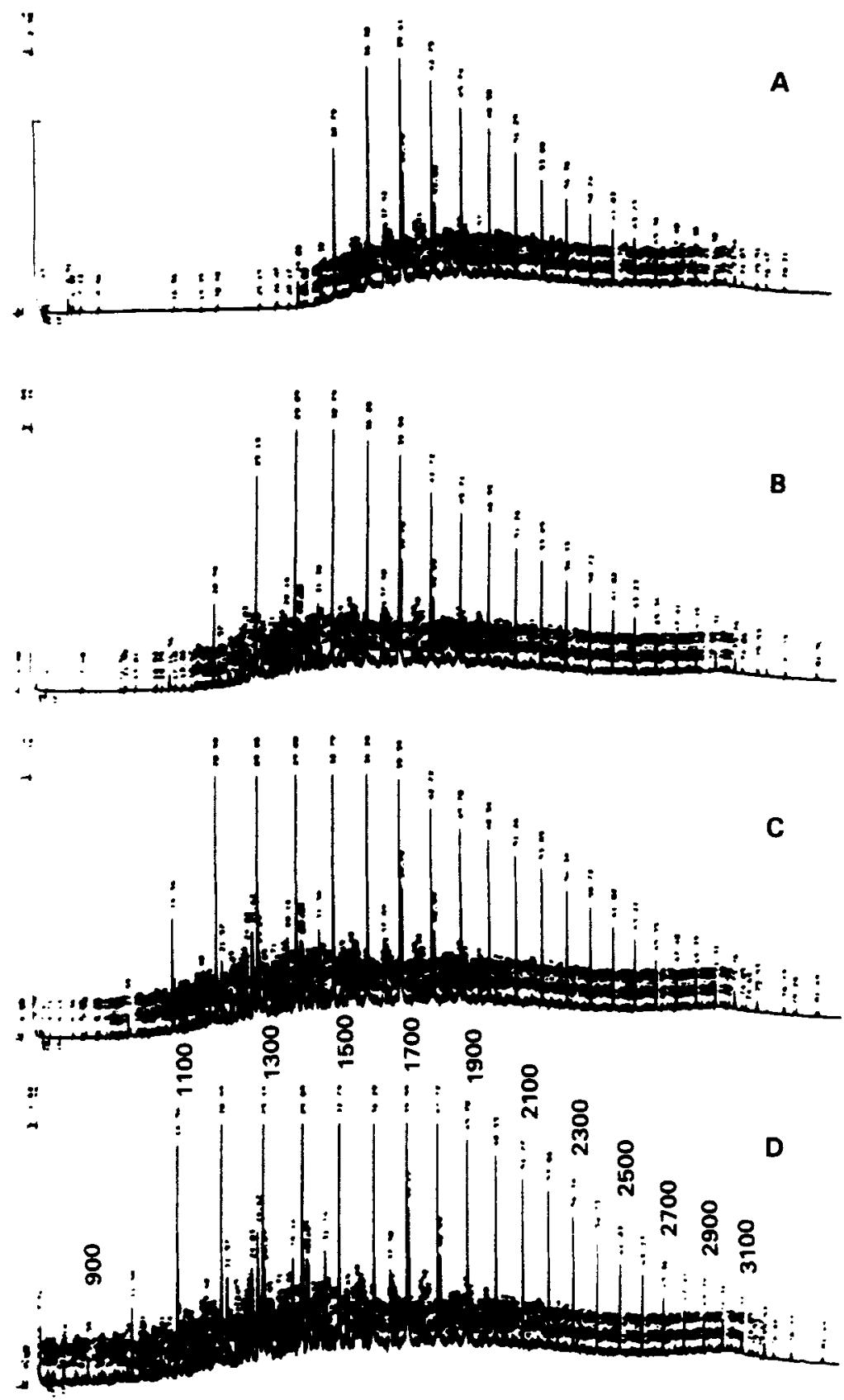

Fig. 15. FID-capillary gas chromatograms of oil stranded on the ice surface with oil thickness of (A) $1 \mathrm{~mm}$, (B) $2 \mathrm{~mm}$, (C) $4 \mathrm{~mm}$, and (D) $5 \mathrm{~mm}$. These samples had been exposed to evaporative weathering under a $5-\mathrm{knot}$ wind at $-20^{\circ} \mathrm{C}$ for approximately 12 hours. 
emulsion formation did not occur until evaporative weathering resulted in much greater losses of the lower molecular weight (less than $n-C_{11}$ ) components (Payne et al. 1984).

\section{Diffusion-controlled evaporation from oil on ice surfaces}

The possibility of diffusion-controlled evaporative weathering was considered by Payne et al. (1984); however, problems with obtaining discrete depth-dependent samples of oil from pan evaporation experiments prevented experimental verification. Successful investigation of this process was conducted for the first time during these cold room wave-tank experiments. An overflow of fresh oil spread to varying thicknesses on the ice surface, allowing the investigation of the diffusion-controlled process. Because of the extremely cold temperature relative to the oil pour point, the fresh oil spread in a horizontal wedge with a thickness of $1 \mathrm{~cm}$ at the point of origin to a film ( $<1 \mathrm{~mm}$ thick) at the farthest distance, $30 \mathrm{~cm}$ away. The oil mass was then exposed to a 5-knot wind at an ambient average temperature of $-20^{\circ} \mathrm{C}$. After 12 hours, samples of the $1-\mathrm{mm}$ thick oil were obtained by scraping the ice surface, melting the shavings, and extracting the water for petroleum hydrocarbon measurements. Depth profiles of the thicker portion of the wedgeshaped oil also were obtained to investigate the relationship of evaporation with depth. The gas chromatogram of the 1-mm oil sample (Fig. 15A) indicated that compounds with molecular weights less than $n-C_{14}$ (b.p. $480^{\circ} \mathrm{F}$ ) were removed within the 12-hour period. An oil sample from the 2mm-thick film showed loss of compounds only below n-C $\mathrm{C}_{12}$ (b.p. $420^{\circ} \mathrm{F}$; Fig. 15B). The chromatograms of 4- and 5-mm-thick oil samples (Figs. 15C and 15D, respectively) indicated that only components with boiling points below 300$350^{\circ} \mathrm{F}$ ( $\mathrm{n}-\mathrm{C}_{9}$ and $\mathrm{n}-\mathrm{C}_{10}$ ) were removed. All of the oil in this wedge was exposed to evaporation weathering for exactly the same time; however, the persistence of the lower molecular weight components in the thicker films indicated that their loss is diffusion-controlled in the oil phase. Thus, a differential residence time of the lower molecular weight components at greater depth in the film would be expected. In thicker oil pools stranded on ice surfaces, evaporation of the complete mass of oil would be diffusion-controlled.
The differences in evaporation rates due to different film thicknesses must be considered in any future weathering model algorithms. A theoretical approach to modeling evaporation from a diffusion-controlled slab was presented in Payne et al. (1984); however, these are the first data that demonstrate the diffusion-controlled process and verify its importance in a model of oil weathering.

\section{Water column concentrations of dissolved aromatic hydrocarbons and whole-oil droplet dispersion}

Concentrations of specific dissolved aromatic hydrocarbons in the water column are presented in Tables 11 and 12 for postspill and post-icebreakup cycles, respectively. Chromatographic profiles of filtered seawater extracts were qualitatively similar to those from the open-ocean wave-tank experiments (Fig. 3) except the absolute concentrations in the water column were controlled by ice dynamics and morphology. Time-series profiles of total dissolved aromatic hydrocarbon concentrations (Fig. 16) illustrate the slight increase in dissolved hydrocarbon concentrations in the water column following subsurface oil release as well as a decrease in hydrocarbon concentrations due to advective

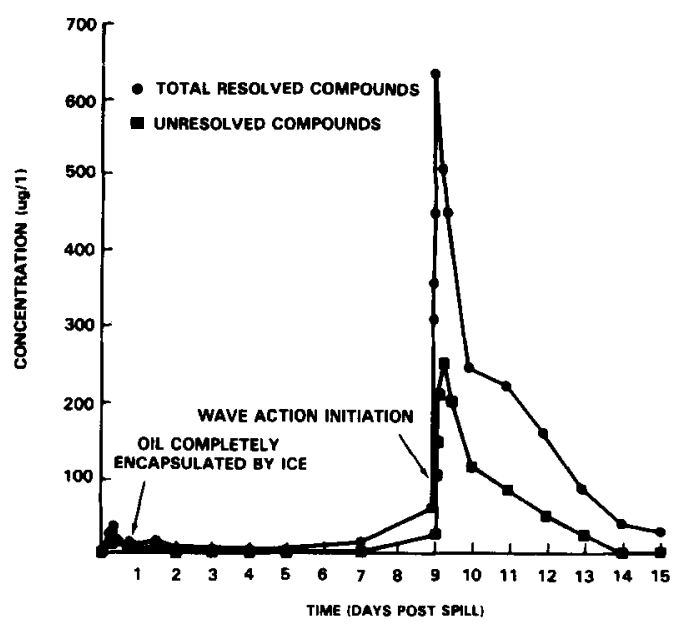

Fig. 16. Time-series dissolved hydrocarbon concentrations (total resolved compounds and UCM) with sea ice present. Note: the $71-\mathrm{cm}$ circular test floe for brine channel oil migration studies was installed on Day 5 and additional leads were cut in the ice canopy on Day 7 (see Table 4). Some dispersion of oil droplets resulting in enhanced dissolution inadvertently occurred during these activities. 


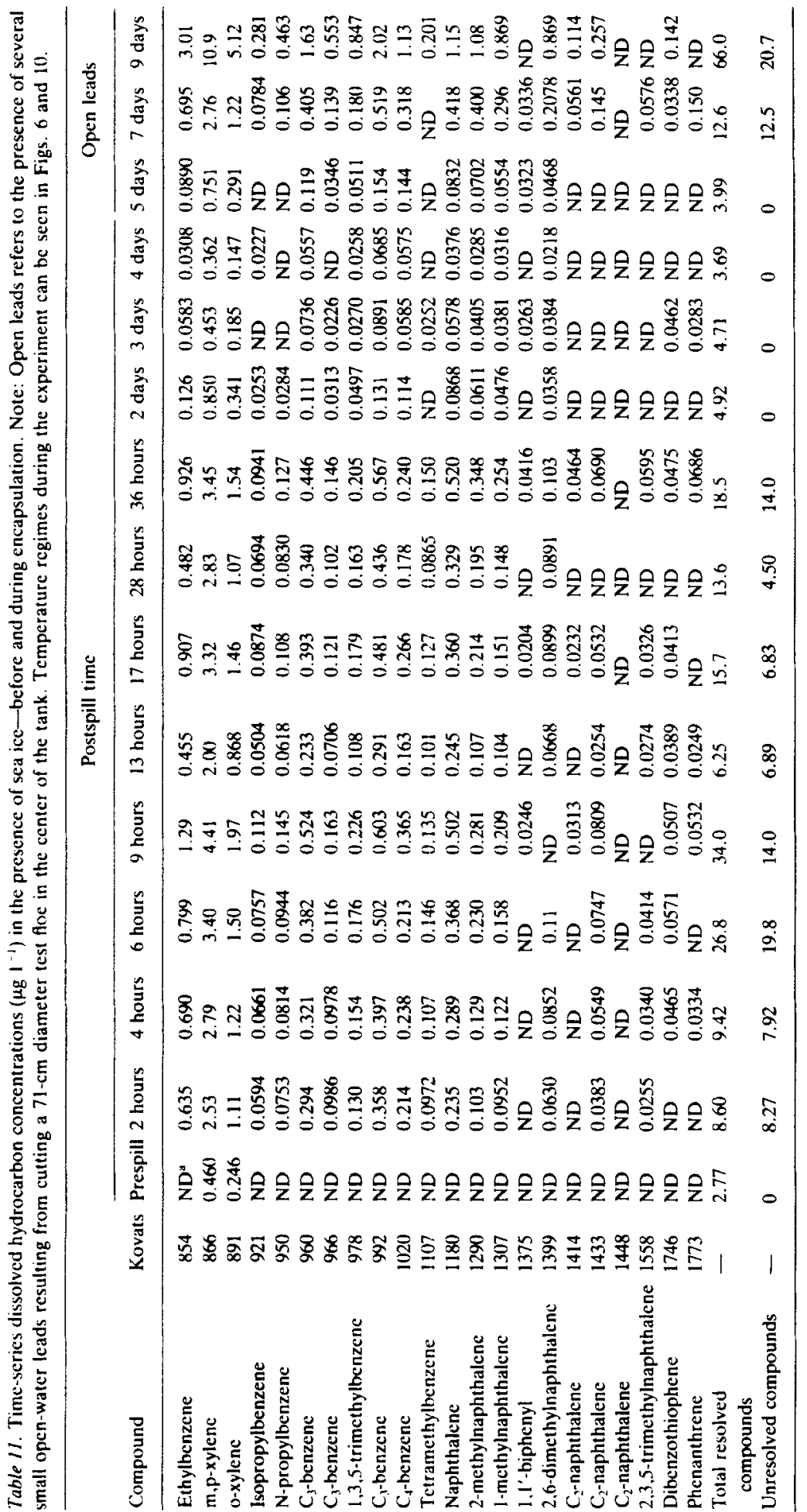




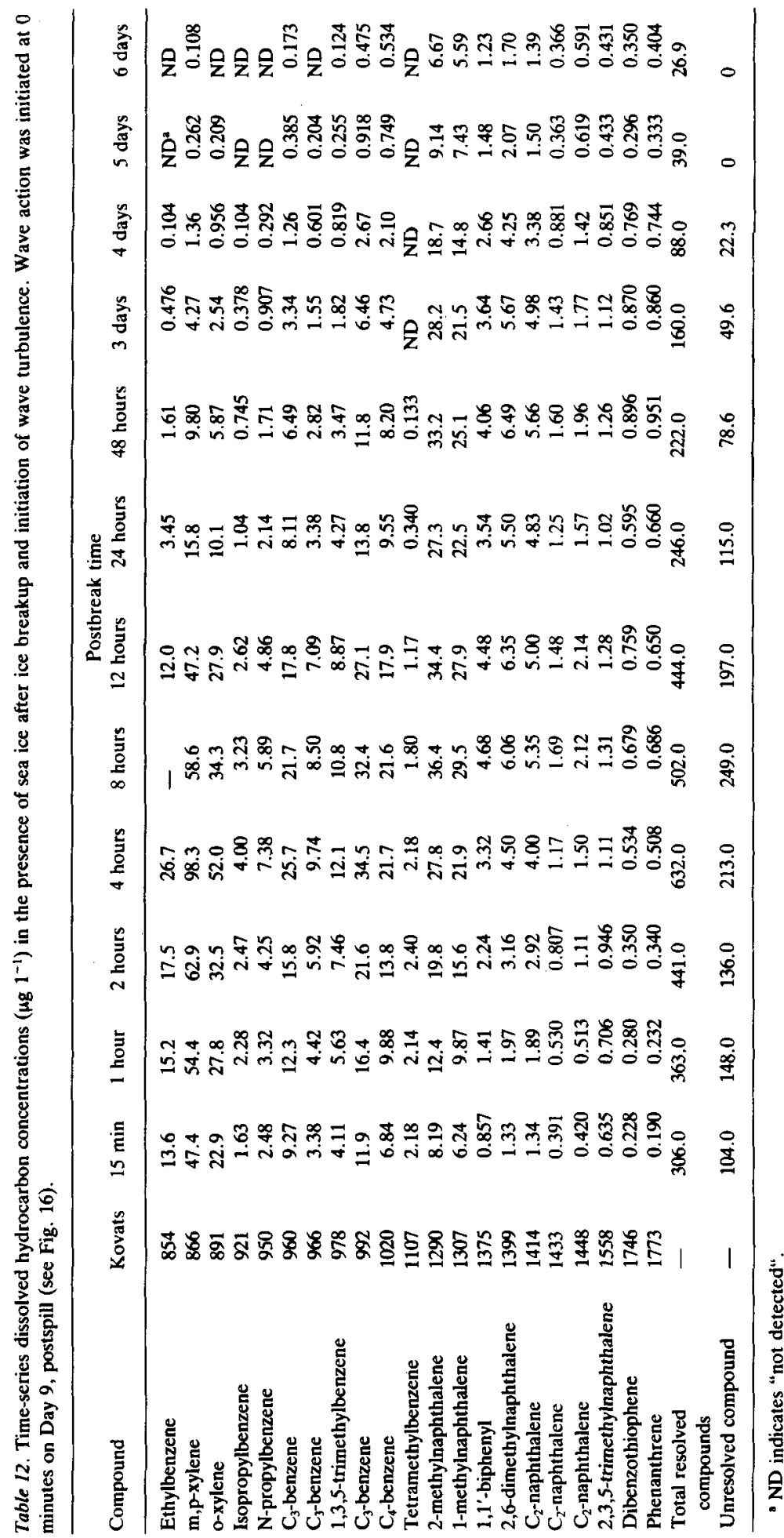




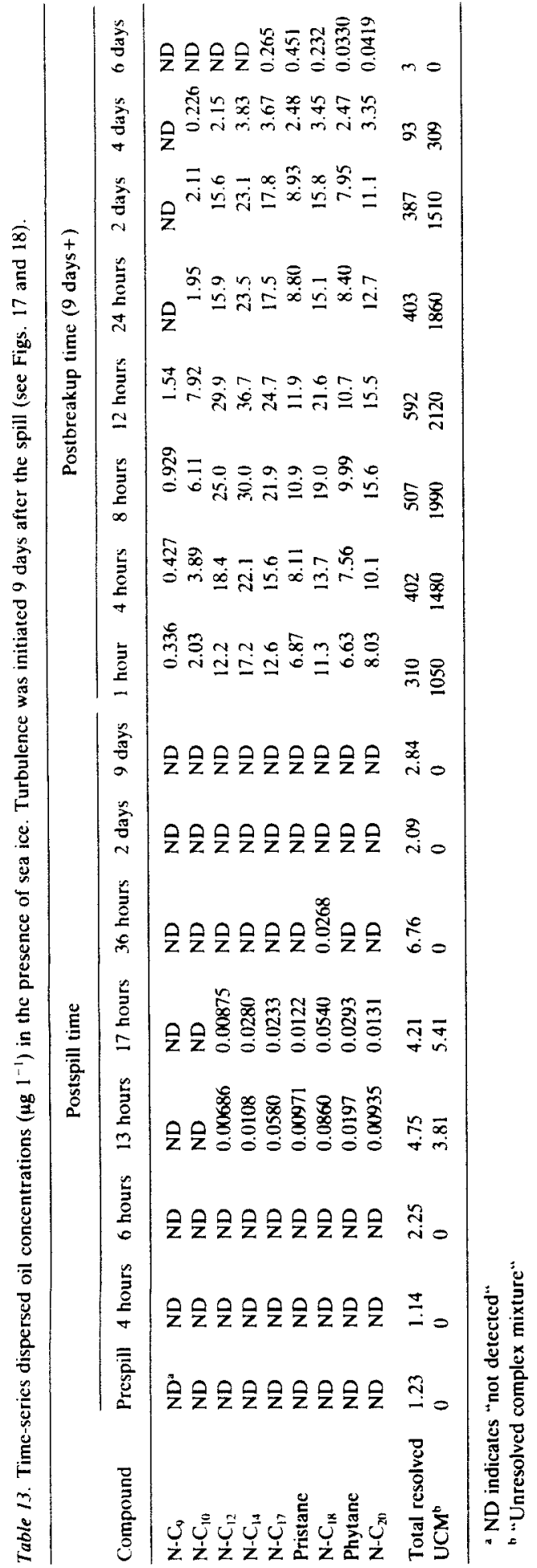

removal processes after oil encapsulation in the ice (Day 3 to Day 4 of the experiment). With the initiation of wave turbulence after ice breakup on Day 9 , however, an approximate 50 -fold increase in individual dissolved hydrocarbon concentrations was observed for the compounds oxylene, trimethylbenzene, naphthalene, and 1,1'biphenyl. The total resolved components and unresolved complex mixtures (determined by FID-GC analyses) increased, respectively, by factors of 700 and 300 following introduction of wave turbulence. This spike in resolved component concentrations then declined gradually (over six days) due to the combined effects of subsurface advection and surface evaporation.

Water samples collected throughout the postspill and postbreakup phases were filtered for FID-GC analyses of dispersed oil droplets. Timeseries concentrations of dispersed oil in the wavetank system are presented in Table 13. Fig. 17 illustrates the time-series concentrations of total resolved and unresolved components in the dispersed-oil phase. Concentrations of total resolved and unresolved complex mixture (UCM) aliphatic hydrocarbons remained low (generally $<10 \mu \mathrm{g}^{-1}$ ) throughout the postspill and oilencapsulation periods, with only relatively small changes from the prespill to the postspill levels. In contrast, levels of dispersed total resolved and UCM hydrocarbons increased by two to three orders of magnitude following the breakup of the ice and the onset of turbulence from a 6-10$\mathrm{cm}$-amplitude wave train. Maximum dispersed hydrocarbon concentrations were measured 12 hours after ice breakup. Concentrations then decreased over the next six days, approximating prebreakup levels. High-viscosity water-in-oil emulsions inhibited further dispersion. Compositionally, the dispersed oil in the water column showed significant evidence of evaporation and dissolution weathering soon after ice breakup. The FID gas chromatograms of the dispersed oil (Fig. 18) show that most of the lower molecular weight $n$-alkanes below $n-C_{10}$ are lost. Compared to open-ocean findings, this more rapid (within one hour of the onset of turbulence) loss of lighter molecular weight components is believed to be due to one or both of the following: significant evaporation of lower molecular weight components while some of the oil was trapped on the ice surface, and/or increased surface-to-volume ratio of the small ( $<1-\mathrm{mm}$ diameter) droplets that were dispersed by the ice matrix compared 
Fig. 17. Time-series water column concentrations of dispersed oil droplets measured by gas chromatographic analysis of water column filter extracts. A. Total resolved compounds. B.

Unresolved complex mixture.
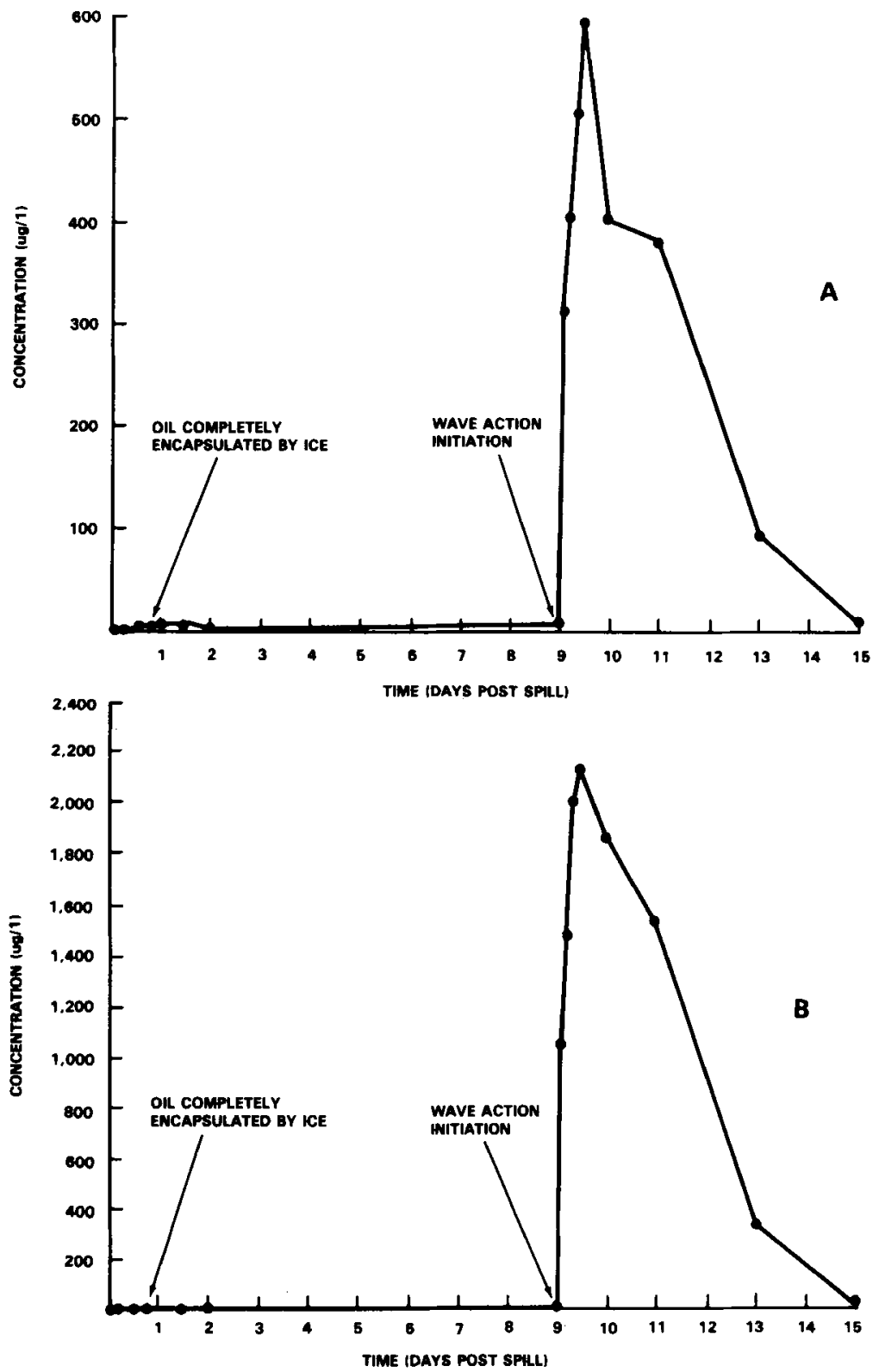

to the larger (3-8-mm diameter) droplets observed in the open-ocean wave-tank simulations.

\section{Transport of dissolved aromatic hydrocarbons} to benthic bottom boundary layers characteristic of ice covered waters in the Chukchi and

\section{Barents Seas}

The dissolution of the lower molecular weight aromatics into the water column during both the outdoor open-ocean wave-tank studies and the cold room ice growth and oil encapsulation experiments led to the investigation of another phenomenon that is unique to Arctic environments. Specifically, a mechanism for brine-mediated transport of dissolved aromatic hydrocarbons to benthic waters in the presence of sea ice also was investigated during these NOAA-sponsored programs (Payne et al. 1987a, 1991b). 

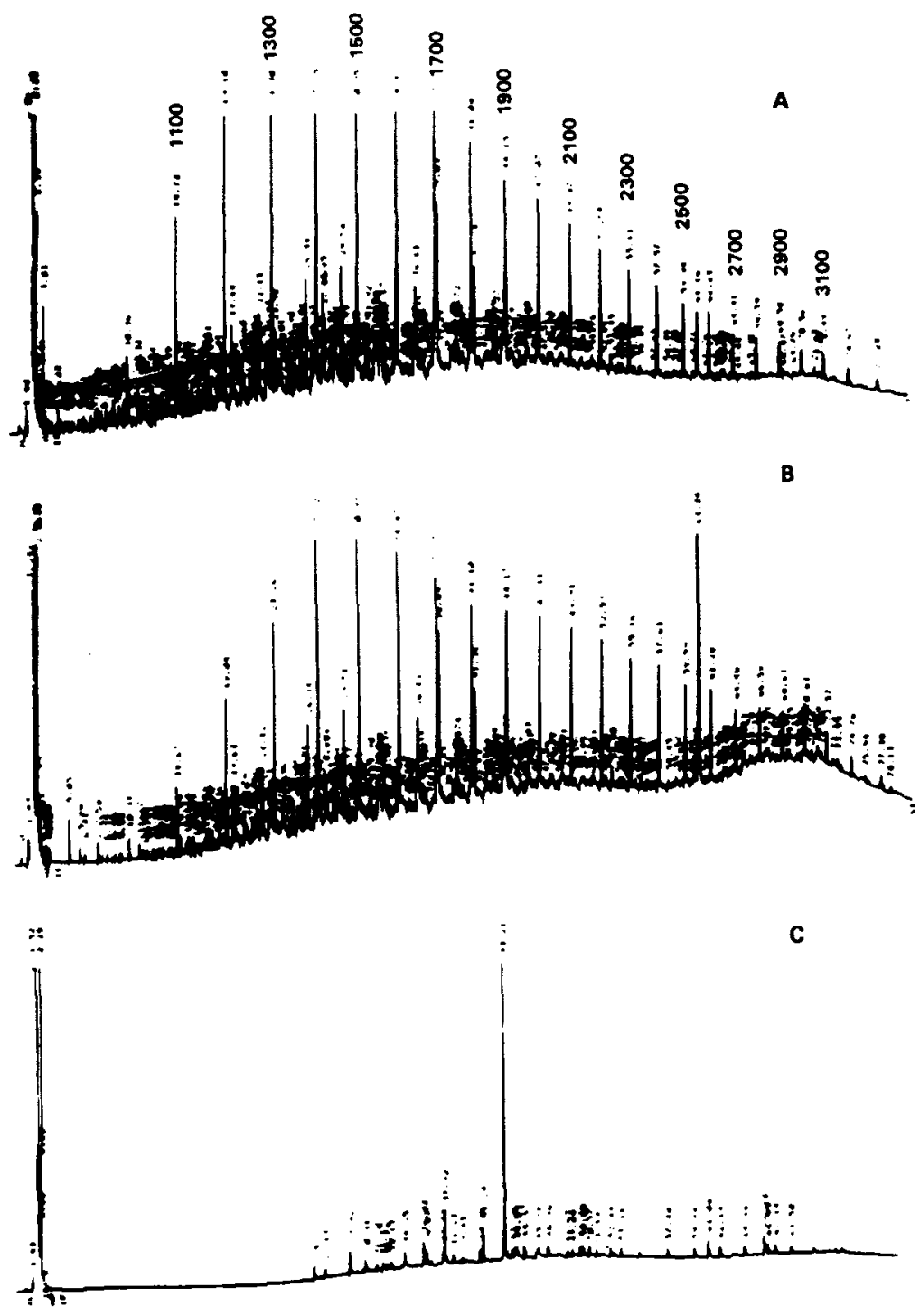

Fig. 18. FID-capillary gas chromatograms of $0.45 \mu \mathrm{m}$ glass fiber filter extracts depicting dispersed oil droplets in the water column (A) one hour. (B) four days, and (C) six days after ice breakup.

During the initial stages of sea ice growth (i.e., frazil, grease, and/or columnar ice formation), brine extruded from the ice to the adjacent seawater results in a localized increase in the salinity (and, thus, density) of the water. In the absence of turbulent mixing and dilution, the higher density water can sink as a relatively discrete mass in a process known as brine cabling (Aagaard 1984). Such behavior leads to the formation of stable benthic bottom boundary layers in portions of the Chukchi Sea. the Barents Sea, and within the barrier lagoons of the Beaufort Sea (Garrison 1977; Hachmeister and Vinelli 1985; Hachmeister et al. 1986). If an oil spill occurred during periods of such ice growth, dissolved aromatic hydrocarbons could be transported as conservative components along with the brine toward the bottom with minimal dilution, where they could persist without evaporation for up to several months.

Preliminary field studies performed during February/March 1984 in the Chukchi Sea and experimental wave-tank studies conducted in January 1985 confirmed that this transport mechanism for dissolved-oil components appeared viable, and an experimental spill with a combined aromatic hydrocarbon compound cocktail was 
performed in an open, but refreezing, lead system near Pt. Franklin in the Chukchi Sea (February/ March 1985). Analyses of water samples collected beneath the surface ice yielded measurable concentrations of both benzene and toluene at selected sampling sites and depths. The distribution of these compounds and their concentrations were explained by a brine-cabling scenario compatible with existing near-bottom currents and simultaneous hydrographic measurements (i.e., salinity, temperature, and density). Therefore, the results of this field effort (Payne et al. 1987a, 1991b), demonstrated the transport of dissolved aromatic hydrocarbon compounds to bottom waters by brine cabling. This process has important biological implications for potential spills from drilling activities during periods of ice growth or from accidental release of oil or refined petroleum products from subsurface pipeline or barge accidents in open lead systems.

\section{Summary and conclusions}

When crude oil or refined petroleum products are released to ice-free marine environments, oil weathering processes occur. These processes include spreading, evaporation, dissolution, dispersion of whole-oil droplets into the water column, photochemical oxidation, water-in-oil emulsification, microbial degradation, adsorption onto suspended particulate material, ingestion by organisms, sinking, and sedimentation. The outdoor flow-through seawater wave-tank studies summarized herein have focused on the changes in oil-phase and water column chemistry to provide compound-specific concentration data that can assist in predicting impacts from open-ocean oil spills. Estimates of advection and dispersion of discrete oil droplets and dissolved aromatic hydrocarbons suggest that significantly lower concentrations of "water-accommodated oil" may be warranted in designing toxicological experiments and in assessing potential environmental impacts from open-ocean oil spills. The wave-tank data also have been used for development and verification of computerized mathematical models to predict oil-weathering behavior. In most cases, very good agreement has been obtained between predicted and observed weathering behavior (Payne et al. 1991a). The model predictions for material balance and weathered-oil composition also have provided useful information during real spill events for estimating potential damage assessments, for contingency planning, and for preparing environmental impact reports for outer continental shelf drilling activities.

When oil is released into ice-covered waters, many of the same weathering processes are in effect; however, the various forms of sea ice impart drastic, if not controlling, changes to the rates and relative importance of these processes. Oil released into a growing slush ice field during late fall or early winter may be subject to stranding on upper ice pan surfaces and rapid water-inoil emulsification, followed by partial densitymediated submersion and incorporation into the ice canopy. For the oil on the upper-ice surface of pans and smaller floes (if present), diffusioncontrolled evaporation weathering predominates; however, for that portion of the oil that remains in the ice/water matrix, the emulsification processes may be rapid enough to occur before significant evaporation and dissolution weathering can reduce the oil toxicity and affect the overall mass balance of the slick. Likewise, oil from a subsurface release under an existing ice canopy is subject to encapsulation before evaporation weathering, although dissolution of aromatics has been demonstrated (and the potential exists for aromatic hydrocarbon transport to the benthos with rejected brine generated during ice growth).

Once encapsulated in the ice, the oil is not subject to further weathering until the spring thaw and ice breakup. The presence of brine channels, which have their origin in the initial freezing process, then becomes especially important during warming periods. As the ice begins to warm, pools maintained as "salt flowers" on the ice surface over winter, as well as brine trapped between the ice crystals, begins to drain through the ice. Oil, initially trapped under or in the ice, then may appear on the upper ice surface due to densitymediated migration up through the open brinechannel pathways. If the oil is emulsified prior to encapsulation, this migration process is retarded significantly, and the presence of temperature gradients within the ice also inhibits such flow. Thus, migration rates for oil in brine channels during the spring thaw may vary as a function of oil chemistry and viscosity (as controlled by water content due to previous emulsification and temperature gradients within the ice), as well as depth in the ice canopy. Rates for brine channel migration of oil trapped in melting first-year ice were presented and contrasted with model predicted behavior. 
Implications for oil released in multiyear ice also were considered. For example, one of the most important aspects of oil weathering in the presence of ice is the role of ice morphology in controlling the rate and extent of stable waterin-oil emulsion formation. Melting first-year ice produced substantial amounts of slush ice, and a stable water-in-oil emulsion of Prudhoe Bay crude oil containing up to $60 \%$ water was formed within four hours of the onset of wave agitation in this slush ice field. In contrast, rotting multiyear ice appeared to have a much lower tendency to produce a slush ice matrix during melting, and the formation of stable water-in-oil emulsions occurred over a relatively longer period of time. In ice-free waters, such emulsion formation was delayed up to three to five days. Rapid formation of stable water-in-oil emulsions is important to potential spill cleanup and containment approaches as well as for in situ burning based on considerations of the lowered combustibility of the emulsions. Such emulsions also would be impossible to disperse chemically. This more rapid emulsion formation also inhibits further evaporation and dissolution weathering, and the more toxic lower and intermediate molecular weight aromatic components are retained in the oil.

Wave-turbulence-induced compression and pumping of oil onto the surface of pancake ice also was observed in the wave-tank experiments. Once the oil was removed from the water surface, evaporation weathering predominated and became diffusion-controlled in the oil phase. At the same time, wave turbulence in the broken ice fields simulated in the cold-room wave tanks was responsible for rapid and appreciable increases in concentrations of dispersed oil droplets in the water column compared to simulated open-ocean conditions. This resulted in significant increases of dissolved component concentrations; however, in the presence of slush ice, this dispersion (and concomitant dissolution) quickly became self-limiting with the rapid onset of stable water-in-oil emulsions that were characterized by high in situ oil viscosities.

Finally, specific mechanisms for brine-induced transport of dissolved aromatic hydrocarbons to benthic ecosystems in actively freezing Arctic waters were recognized during these studies. If oil is released into water under freezing conditions of active ice growth, lower molecular weight aromatic components can be advected with the sink- ing brine generated during frazil ice formation to the stable bottom boundary layer where, as conservative dissolved compounds, they can persist without evaporation for periods of up to several months.

Acknowledgements. - These studies were funded by the U.S. Minerals Management Service through Interagency Agreement with the U.S. National Oceanic and Atmospheric Administration. as part of the Outer Continental Shelf Environmental Assessment Program (Contract Numbers NA80RACOO018 and 84-AK-00121 with Science Applications International Corporation. San Dicgo. California, USA). Additional funding for research on oil/first-year ice interactions also was provided through a U.S. Coast Guard/OCSEAP Interagency Agreement. C. A. Manen is gratefully acknowledged for her continued support and interest as the NOAA Contracting Officer's Technical Representative throughout the open-ocean and oilin-ice oil weathering studies. S. Martin at the University of Washington was extremely helpful through his assistance in the design and execution of cold room/wave tank studies at Kasitsna Bay. P. A. Tebeau, USCG Research and Development Center, is gratefully acknowledged for his interest and support in the area of vertical migration of oil in brine channels, evaporation, and emulsification. The sustained efforts of R. and L. Geagel in completing the design and fabrication of the cold room and wave-tank system at the NOAA Kasitsna Bay laboratory are gratefully acknowledged.

\section{References}

Aagaard, K. 1984: Currents, CTD and pressure measurements in possible dispersal regions of the Chukchi Sea. NOAA/ OCSEAP Final Report, RU $91.77 \mathrm{pp}$.

Armstrong, T. E., Roberts, B. B. \& Swithinbank, C. W. M. 1966: Illustrated glossary of snow and ice. Spec. Publ. 4, 18. Scott Polar Research Institute, Cambridge, England.

Barber. F. G. 1970: Report of the task force: operation oil (Cleanup of ARROW oil spill in Chedabucto Bay), Vol. III, 35-54. Canada Ministry of Transport, Ottawa. Cat. No. T222470.

Barnes, P., Reimnitz, E., Toimil L. \& Hill, H. 1979: U.S. Geol. Surv. Open-File Rept. 79-539.

Bartha, R. \& Atlas, R. M. 1987: Transport and transformations of petroleum: biological processes. Pp. 287-341 in Boesch, D. F. \& Rabalais, N, N. (eds.): Long-term environmental effects of offshore oil and gas development. Elsevier Applied Science. London and New York.

Bauer. J. \& Martin, S. 1983: A model of grease ice growth in small leads. J. Geophys. Res. 88, 2917-2925.

Berridge. S. A. Dean. R. A.. Fallows, R. G. \& Fish. A. 1968a: The properties of persistent oils at sea. Pp. 2-11 in Hepple, P. (cd.): Proceedings of a symposium, scientific aspects of pollution of the sea by oil. Institute of Petroleum. London.

Berridge, S. A., Thew, M. T. \& Loriston-Clarke, A. G. 1968b: The formation and stability of emulsions of water in crude petroleum and similar rocks. J. Inst. Petroleum 54, 333-357.

Boehm. P. D. 1987: Hydrocarbon and metal pollutants in offshore sedimentary environments. Pp. 233-286 in Boesch, D. F. \& Rabalais, N. N. (eds.): Long-term environmental effects of offshore oil and gas development. Elscvier Applied Science, London and New York. 
Bridie, A. L., Wanders, Th. H.. Zcgueld, W. \& Van der Heijde, H. B. 1980a: The formation, prevention and breaking of sea-water-in crude-oil emulsions: "chocolate mousse". Pp. 33-39 in Mackay. D., Wells. P.G. \& Paterson. S. (eds.): Chemical Dispersion of Oil Spills: An International Research Symposium, Institute for Environmental Sciences, University of Toronto, Ontario, Canada (Nov. 17-19. 1980). Pub. No. EE-17.

Bridie, A. L., Wanders, Th. H., Zegueld, W. \& Van der Heijde, H. B. 1980b: Formation, prevention and breaking of sea water in crude oil emulsions "chocolate mousses". Mar. Poll. Bull. 2, 343-348.

Canevari, G. P. 1985: The effect of crude oil composition on dispersant performance. Proceedings of the 1985 Oil Spill Conference, 441-444. American Petroleum Institute, Washington, D.C.

C-Core, 1975: An oil spill in pack ice. Memorial University of Newfoundland, St. Johns, Newfoundland.

Clark, R. C. \& Brown, D. W. 1977: Petroleum: properties and analyses in biotic and abiotic systems. Pp. 1-89 in Malins, D. C. (ed.): Effects of petroleum on arctic and subarctic marine environments and organisms, Vol. I. Academic Press, New York.

Clark, R. C. \& MacLeod, W. D. 1977: Inputs, transport mechanisms and observed concentrations of petroleum in the marine environment. Pp. 91-223 in Malins, D. C. (ed.): Effects of petroleum on arctic and subarctic marine environments and organisms, Vol I. Academic Press, New York.

Coleman, H. J., Shelton, E. M., Nichols, D. T. \& Thompson, C. I. 1978: Analysis of 800 Crude Oils from United States Oil Fields. BETC/PRI-78/4, Bartlesville Energy Technology Center, Bartlesville, Oklahoma.

Cox, J. C., Schultz, L. A., Johnson, R. P. \& Shelsby, R. A. 1981: The transport and behavior of oil spilled in and under sea ice. Environmental assessment of the Alaskan continental shelf, Final Reports, Physical Science Studies 3, 427-597. NOAA/OCSEAP, Boulder, Colorado.

Garrison, G. R. 1977: Oceanographic measurements in the Chukchi Sea and Baffin Bay-1976. APL-University of Washington Technical Report 7710. 44 pp.

Gold, P. I. 1969: Estimating Thermophysical Propcrtics of Liquid, Part 10: Viscosity. Chemical Engineering 76 (15). 121-124.

Hachmeister, L. E. \& Vinelli, J. B. 1985: Nearshore and coastal circulation in the northeastern Chukchi Sea. In Environmental assessment of the Alaskan continental shelf. Final reports of principal investigators. National Oceanic and Atmospheric Administration/Outer Continental Shelf Environmental Assessment Program: Anchorage, Alaska. $93 \mathrm{pp}$.

Hachmeister, L. E., Short, K. S., Schrader, G. D., Winnick, K. B. \& Johannessen, J. W. 1985: Oceanographic Monitoring. In 1985 Final Report for the Endicott Environmental Monitoring Program, Vol. 3., 1986, Prepared for the U.S. Department of the Army, Alaska District, Corps of Engineers by Envirosphere Co., Bellevue, Washington. $160 \mathrm{pp}$.

Haines, J. R. \& Alexander, M. 1974: Microbial degradation of high-molecular weight alkanes. Appl. Microbiol. 28, 1084 1085.

Jordan, R. E. \& Payne, J. R. 1980: Fate and weathering of petroleum spills in the marine environment: $A$ literature review and synopsis. Ann Arbor Science Publishers, Ann Arbor, Michigan. 174 pp.

Kovats, von E. 1958: Gas-chromatographische charakter- isierung organischer verbindungen, Teil 1: Retentionsindices aliphatischer halogenide, alkohole, aldehyde und ketone. Helvetica Chimica Acta 260, 1915-1932.

Martin, S. 1979: A field study of brine drainage and oil entrainment in first-year sea ice. J. Glaciol. 22, 473-502.

Martin, S. 1981a: Anticipated oil-ice interactions in the Bering Sea. Pp 223-243 in Hood, D. W. \& Calder, J. A. (eds.): The eastern Bering Sea shelf: oceanography and resources, Vol. I, University of Washington Press, Seattle, Washington.

Martin, S, 1981b: Frazil ice in rivers and oceans. Ann. Rev. Fluid Mech. 13, 379-397.

Martin, S. \& Kauffman, P. 1981: A field and laboratory study of wave damping by grease ice. J. Glaciol. 27, 283-314.

NAS 1985: Oil in the sea: inputs, fates and effects. National Academy Press, Washington, D.C. $601 \mathrm{pp}$.

NAS 1989: Using oil spill dispersants on the sea. National Academy Press, Washington, D.C. 335 pp.

NORCOR 1975: The interaction of crude oil with Arctic sea ice. Beaufort Sea Technical Report No. 27. Beaufort Sea Project, Environment Canada, Victoria, B.C., Canada.

Payne, J. R. \& Floyd, M. S. 1990; Petroleum and chlorinated hydrocarbon analysis in support of in vitro studies of natural anaerobic and aerobic microbial degradation of xenobiotics in contaminated groundwater and soil. Intern. J. Environ. Anal. Chem. 39, 101-120.

Payne, J. R. \& McNabb, Jr., G. D. 1984: Weathering of petroleum in the marine environment. Marine Technology Soc. J. 18(3), 24-42.

Payne, J. R. \& Phillips, C. R. 1985a: Petroleum spills in the marine environment: the chemistry and formation of waterin-oil emulsions and tar balls. Lewis Publishers, Chelsea, Michigan. $150 \mathrm{pp}$.

Payne, J. R. \& Phillips, C. R. 1985b: Photochemistry of petroleum in water. Environ. Sci. Technol. 19(7), 569-579.

Payne, J. R., Kirstein, B. E., McNabb, Jr., G. D., Lambach, J. L., de Oliveira, C., Jordan, R. E. \& Hom, W. 1983: Multivariate analysis of petroleum hydrocarbon weathering in the subarctic marine environment. Proceedings of the 1983 Oil Spill Conference, 423-434. American Petroleum Institute, Washington, D.C.

Payne, J. R., Kirstein, B. E., McNabb, Jr., G. D., Lambach, J. L., Redding, R., Jordan, R. E., Hom, W., de Oliveira, C., Smith, G. S., Baxter, D. M. \& Geagel, R. 1984: Multivariate analysis of petroleum weathering in the marine environment-subarctic. Vol. I \& II. In Environmental assessment of the Alaskan continental shelf, final reports of principal investigators. U.S. Dep. Commer. NOAA, OCSEAP Final Rep. 21 \& 22 (1984). 690 pp.

Payne, J. R., McNabb, Jr., G. D., Hachmeister, L. E., Kirstein, B. E., Clayton, Jr., J. R., Phillips, C. R., Redding, R. T.. Clary, C. L., Smith, G. S. \& Farmer, G. H. 1987a: Development of a predictive model for the weathering of oil in the presence of sea ice. Outer continental shelf environmental assessment program, final reports of principal investigators, 147-465. U.S. Dep. Commer. NOAA, OCSEAP Final Rep. 59 (1988).

Payne, J. R., Kirstein, B. E., Clayton, Jr., J. R., Clary, C., Redding, R., McNabb, Jr., G. D. \& Farmer, G. 1987b: Integration of suspended particulate matter and oil transportation study. Final report submitted to Minerals Management Service, Environmental Studies Branch, Anchorage, Alaska. (MMS Contract No. 14-12-0001-30146). 261 pp.

Payne, J. R., Phillips, C. R. \& Hom, W. 1987c: Transport and 
transformations: water column processes. Pp. 175-231 in Boesch, D. F. \& Rabalais, N. N. (eds.): Long-term environmental effects of off-shore oil and gas development. Elsevier Applied Science, London and New York.

Payne, J. R., Clayton, Jr., J. R., McNabb, Jr. . G. D. , Kirstein, B. E., Clary, C. L., Redding, R. T., Evans. J. S., Reimnitz, E. \& Kempema, E. W. 1989: Oil-ice-sediment interactions during freezeup and breakup. Outer continental shelf environmental assessment program. final reports of principal investigators, 1-382. U.S. Dep. Commer. . NOAA. OCSEAP Final Rep. 64 (1989).

Payne, J. R. , Clayton. Jr.. J. R., McNabb, Jr., G. D. \& Kirstein, B. E. 1991a: EXXON VALDEZ oil weathering fate and behavior: model predictions and field observations. Proceedings of the 1991 Oil Spill Conference, 641-654. American Petroleum Institute, Washington, D.C.
Payne, J. R., Hachmeister, L. E., McNabb, Jr., G. D., Sharpe, H. E., Smith, G. S. \& Manen, C. A. 1991b: Brine induced advection of dissolved aromatic hydrocarbons to arctic bottom waters. Environ. Sci. Technol. 25(5), 940-951.

Pirnik. M. P. 1977: Microbial oxidation of methyl branched alkanes. Crit. Rev. Microbiol. 5, 413-422.

Thomas, D. R. 1980: Behavior of oil spills under sea icePrudhoe Bay. Flow Research Report No. 175. Flow Research Co.. Kent, Washington. 124 pp

Twardus, E. M. 1980: A study to evaluate the combustibility and other physical and chemical properties of aged oils and emulsions. R \& D Division, Environmental Emergency Branch, Environmental Impact Control Directorate, Environmental Protection Service, Environment Canada, Ottawa. Ontario.

Weeks, W. F. \& Weller, G. 1984: Offshore oil in the Alaskan Arctic. Science 225, 371-378. 